\title{
Extreme erosion on high-energy embayed beaches: influence of megarips and storm grouping
}

Carlos Loureiro ${ }^{a^{*}}$

Óscar Ferreira ${ }^{a}$

Andrew Cooper ${ }^{b}$

a CIMA, Centre for Marine and Environmental Research, Universidade do Algarve, Campus de Gambelas, Faro 8005-139, Portugal

${ }^{b}$ Centre for Coastal and Marine Research, School of Environmental Sciences, University of Ulster, Cromore Road, Coleraine BT52 1SA, Northern Ireland, UK

* Corresponding author

Email:carlos.loureiro@stir.ac.uk, oferreir@ualg.pt, jag.cooper@ulster.ac.uk

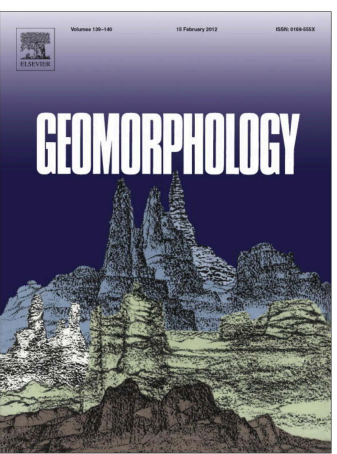

Published in:

Geomorphology

Volume 139-140, February 2012, Pages 155-171

DOI: 10.1016/j.geomorph.2011.10.013

URL: https://www.sciencedirect.com/science/article/pii/S0169555X11005290

Geomorphology 139-140 (2012) 155-171

Contents lists available at SciVerse ScienceDirect

Geomorphology

journal homepage: www.elsevier.com/locate/geomorph

Extreme erosion on high-energy embayed beaches: Influence of megarips and storm grouping

Carlos Loureiro ${ }^{\mathrm{a}, *}$, Óscar Ferreira ${ }^{\mathrm{a}}$, J. Andrew G. Cooper ${ }^{\mathrm{b}}$

a CIMA, Centre for Marine and Environmental Research, Universidade do Algarve, Campus de Gambelas, Edifício 7, 8005-139 Faro, Portugal

b Centre for Coastal and Marine Research, School of Environmental Sciences, University of Ulster, Cromore Road, Coleraine BT52 1SA, Northern Ireland, United Kingdom

A R T I C L E I N F O A B S T R A C T

This post-print author's version of the manuscript is licensed under a Creative Commons AttributionNonCommercial-NoDerivatives 4.0 International License 


\section{Research highlights:}

$>$ Storm-induced megarips exert a major influence on beach erosion.

$>$ Megarip impact is persistent and cumulative during storm-groups.

$>$ Megarips can persist for several months enhancing beach erosion and reducing beach recovery ability. 
1 Extreme erosion on high-energy embayed beaches: influence of megarips

2

3 and storm grouping

Carlos Loureiro $^{\mathrm{a}, 1}$, Óscar Ferreira ${ }^{\mathrm{a}}$ and J. Andrew G. Cooper ${ }^{\mathrm{b}}$

${ }^{\text {a } C I M A ~-~ C e n t r e ~ f o r ~ M a r i n e ~ a n d ~ E n v i r o n m e n t a l ~ R e s e a r c h, ~ U n i v e r s i d a d e ~ d o ~ A l g a r v e, ~ C a m p u s ~}$ de Gambelas, Edifício 7, 8005-139 Faro, Portugal

cloureiro@ualg.pt; oferreir@ualg.pt

${ }^{\mathrm{b}}$ Centre for Coastal and Marine Research, School of Environmental Sciences, University of Ulster, Cromore Road, Coleraine BT52 1SA, Northern Ireland jag.cooper@ulster.ac.uk

${ }^{1}$ Corresponding author: CIMA - Centre for Marine and Environmental Research, Universidade do Algarve, Campus de Gambelas, Edifício 7, 8005-139 Faro, Portugal, Telephone: +351 289800900 (ext: 7885), Fax:+351 289800969, Email: cloureiro@ualg.pt

\section{Abstract}

Megarips have long been recognized as an important, yet poorly documented, mechanism of beach erosion on high-energy embayed beaches. The persistence and cumulative effect of megarips during storm groups, are described from three embayed beaches (Arrifana, Mt. Clérigo and Amoreira) exposed to high-energy wave conditions in the mesotidal, bedrockdominated southwestern coast of Portugal. Morphological changes, determined by topographic monitoring and supplemented by interpretation of digital imagery over two years, revealed the development of storm-induced megarips, which exerted a major influence on beach erosion. Differences in megarip influence within and between beaches are related to embayment geometry and orientation, which significantly influence the nearshore wave field. Rip location is topographically controlled, being determined by alongshore variations in breaking wave height and obliquity, along with interaction of wave-driven circulation patterns 
and embayment nearshore topography. Moderate beach sand loss during individual storms was linked to the development of megarips with associated rip-neck and feeder channels. Extreme erosion, however, occurred when megarips and feeder channels persisted during successive storms, promoting continued erosion and seaward sediment export. Observations show that once initiated, megarip channels persist for several months and continue to act as conduits for offshore sediment transport under non-storm conditions. The maintenance of such rip circulation systems, driven by morphodynamic feedback, reduces beach recovery ability until the rip-neck and feeder channels are infilled.

Keywords: embayed beaches, megarips, storm groups, beach morphology, wave modelling, Portugal

\section{Introduction}

Severe erosion on embayed beaches has long been associated with the occurrence of large scale rip currents, or megarips (Short, 1985). Megarips occur when the embayment topography, particularly around headlands, alters surf zone dynamics during high waves, inducing persistent longshore gradients and the development of cellular circulation (Short and Masselink, 1999). Due to high offshore flow velocities and the seaward extent of megarips (beyond the surf zone), sediment is removed from the beach and transported seaward, to the lower shoreface or even the inner shelf (Short, 1985; Short and Masselink, 1999; Short, 2010).

The influence of embayed beach configuration in the location and dynamics of large scale rip currents was presented early in the rip current literature by McKenzie (1958). However, recent advances in understanding of rip current flow kinematics and morphological coupling have been based on rip channelled beaches on open coastlines, rather than topographic rips 
and megarips (MacMahan et al., 2006, 2010). Apart from the first records of megarip flow on the nearshore by Evans et al. (2000) and Coutts-Smith (2004), no other measurements of megarip flow have yet been made in the beach or surfzone. The highly dynamic and energetic conditions associated with the occurrence of megarips make instrument deployment hazardous, and have constrained attempts to measure megarip dynamics. Nevertheless, megarips have been associated with extreme beach and even foredune erosion during major storm events along high-energy embayed coastlines (e.g. Thom, 1974; Short and Hesp, 1982), and offshore sediment transport from beaches (e.g. Coutts-Smith, 2004; Smith et al., 2010). On unconstrained sandy beaches, severe erosion is traditionally associated with extreme single storms. However, the occurrence of storm groups has become a focus of renewed attention, since the combined erosion of successive storms can be similar or even higher than a single storm of higher magnitude (Lee et al., 1998; Ferreira, 2005, 2006; Callaghan et al., 2008). High-energy embayed beaches exposed to energetic swell and storms are considered to be attuned to high-energy conditions and, therefore, require extreme events to cause significant morphological change (Cooper et al., 2004). However, the morphological impacts of such extreme events on embayed beaches, particularly storm groups, remain little studied, except for the early report of Thom (1974). Consequently, the cumulative effects of successive high-energy events on morphodynamic responses in embayed beaches (e.g. beach rotation, megarip development and headland sand bypassing) are still poorly understood.

This paper presents observations of morphological change, obtained during frequent surveys on three sandy embayed beaches in the southwestern coast of Portugal, exposed to highenergy wave conditions in a mesotidal environment. Wave data was obtained for an offshore location and propagated to the nearshore using numerical wave modelling, in order to investigate the morphological response to wave forcing. Previous work (Loureiro et al., 2011) has indicated that the general pattern of seasonal change along the study sites is disturbed by 
storm-group action which induces dramatic beach erosion, and that beach response is not uniform alongshore.

The overall aim of this paper is to examine the role of megarips and storm grouping in the extreme erosion observed in embayed beaches exposed to high-energy wave conditions. The specific objectives are to: (i) quantify the volumetric and morphological beach response to wave forcing, particularly focusing on the impact of storm groups and the development of rip current systems; (ii) analyse the conditions for megarip development in the three beaches based on morphodynamic behaviour parameters and numerical wave modelling; and (iii) evaluate the role of storm grouping in the persistence and enhanced action of megarips and discuss the impacts on extreme erosion and recovery ability of embayed beaches.

\section{Environmental setting}

Along the bedrock-dominated southwestern coast of Portugal, beaches occur generally in embayments associated with small streams or in coastal re-entrants within the Carboniferous shale and greywacke cliffs. The coast is directly exposed to the North Atlantic swell, experiencing mean offshore significant wave heights $\left(H_{s o}\right)$ between 1.5 and $2 \mathrm{~m}$ and peak periods $\left(T_{p}\right)$ between 9 and $13 \mathrm{~s}$, predominantly from northwest to westerly directions $(\theta)$ (Fig. 1) (Costa et al., 2001; Costa and Esteves, 2010). Energetic wave conditions are relatively frequent, with $H_{s o}$ exceeding $3 \mathrm{~m} \mathrm{10 \%}$ of the time (Costa et al., 2001). Storms along the western Portuguese coast are associated with $H_{s o} \geq 5 \mathrm{~m}$ (Pita and Santos, 1989), and are generally caused by frontal systems connected with high to mid-latitude depressions crossing the North Atlantic (Costa et al., 2001). Storm groups occur frequently on the west coast of Portugal, once every year for a group of two storms and once every four years for a group of three storms (Ferreira, 2005). Storm groups may also be associated with the landfall of frontal systems. Their occurrence is related to a southerly position of the Azores High Pressure 
System, which allows successive depressions to follow a more southerly path and impact directly on the Portuguese coast. Individual storms with high waves usually last an average of two days, but occasionally they can persist for more than five days (Costa et al., 2001; Costa and Esteves, 2010).

Tides along the south-western coast of Portugal are semidiurnal and mesotidal, with maximum spring tidal range of $3.6 \mathrm{~m}$ and maximum tidal elevation about $2 \mathrm{~m}$ above mean sea level (MSL).

\section{Figure 1}

Field surveys were conducted in Arrifana, Mt. Clérigo Amoreira and beaches (Fig. 1), the former two directly exposed to the dominant north-westerly waves while Arrifana roughly faces west and is partially protected by a prominent northern headland. All three beaches are composed of well-sorted, medium sand and, being exposed to a high-energy wave climate, are modally dissipative or intermediate skewed to dissipative in state. Arrifana is a swash-aligned beach, completely enclosed by up to $100 \mathrm{~m}$-high cliffs, and separated from them by coarse gravel and boulders deposit. The subaerial beach is narrow, rarely presenting a well defined berm, while the intertidal area is wide and flat and frequently featureless. A wide and flat intertidal area also characterizes Mt. Clérigo, yet the subaerial beach is wide and backed by partly vegetated dunes in the south and centre, while the northern sector is narrow and backed by $50 \mathrm{~m}$-high cliffs. Amoreira beach is wide and backed by an extensive dune field. This embayment contains a bay-barrier estuary, with a small tidal stream. The beach has a persistent low tide terrace that is occasionally crossed by a migrating tidal channel. This creates a ridge and runnel-like morphology and produces a recurring planform rotation of 
Amoreira beach that is driven by the interaction of fluvial discharge and oceanographic forcing (Freire et al., 2011).

\section{Methods}

\subsection{Beach and nearshore morphology}

Morphological surveys were conducted in Arrifana, Mt. Clérigo and Amoreira beaches along cross-shore beach profiles over a two year period, between September 2007 and September 2009. Surveys were undertaken regularly every two months, and were complemented by event-driven surveys performed immediately after storms and 15 to 30 days later to monitor beach recovery, totalling 20 surveys completed on each beach over the two year period. Three profiles representative of the different beach sectors and with alongshore profile spacing between 200 and 100 m (Fig. 1), were monitored on each beach using a Trimble RTK-GNSS (Real Time Kinematic Global Navigation Satellite System). Surveys were always performed at low tide, preferentially during spring tides, and extended from the frontal dune or cliff base to waning depths, at least up to the mean low water spring level (MLWS), $1.4 \mathrm{~m}$ below mean sea level (MSL), or further seaward.

Volumetric change was computed for each profile (in $\mathrm{m}^{3}$ per unit metre of beach length) by integrating the beach profile above the MLWS level. Recognition of a nodal point at approximately the MLWS level, separating berm and subtidal terrace changes on an exposed beach in Southern Portugal by Almeida et al. (2011), suggests a vertical morphodynamic separation of the profile at this level and, therefore, renders it as an appropriate lower level for beach volume calculation. Net gain or loss of sediment over the MLWS level is then considered an indicator of cross-shore exchange of sediment between (i) the subaerial and intertidal beach and (ii) the subtidal beach. 
Detailed topo-bathymetric surveys of the all three beaches and nearshore areas were performed in September 2008, during a period of general beach accretion, using a boatmounted single beam echosounder, RTK-GNSS positioning and tidal correction. Survey lines, spaced at 100 to $150 \mathrm{~m}$ intervals, extended seaward from the beach between 1 and $2 \mathrm{~km}$, reaching depths of approximately $30 \mathrm{~m}$ bellow MSL. Prior to grid interpolation, raw survey data was smoothed using a moving average with a $50 \mathrm{~m}$ window, considered suitable to resolve nearshore sandbars at the study area. After smoothing, the bathymetric grids were produced using a locally adapted spline interpolation, which retained the general smoothness of the nearshore area, but also allowed for sharp changes along submerged rocky outcrops to be represented.

\subsection{Rip and feeder configuration}

Recent studies of rip systems at mesocale (months to years) have been based in visual identification of rip channels, mostly using video imaging techniques (e.g. Ranasinghe et al., 2004; Holman et al., 2006; Turner et al., 2007; Orzech et al., 2010, Gallop et al., 2011). However, on the majority of cases, these are subjective methods based on manual visual analysis (Gallop et al., 2011), and have been particularly noted to be of limited use in energetic conditions, when megarips develop (Short, 1985), as large waves break across the entire surfzone, hampering the identification of rip channels (Orzech et al., 2010; Gallop et al., 2011). Repeated bathymetric surveys have been also used to characterize rip morphology, but only during short-term field experiments covering restricted areas (e.g. MacMahan et al., 2005) due to the logistical difficulties involved in monitoring the surfzone and nearshore in dynamic and energetic environments where rip currents develop (Brander et al., 2001). In the present work, a combined analysis of visual evidence and morphological patterns, synthesized in Fig. 2, is used to identify rip-neck and feeder channels and assess their 
interaction with beach profiles, in an attempt to overcome the shortcomings identified above. Shallow nearshore bars and rip channels along the shoreline and surfzone are relatively easy to identify visually (Holman et al., 2006; Thornton et al., 2007; Turner et al., 2007). Increased turbulence due to wave-current interactions, gaps in the breaking line, streaks of darker water and foam patches seaward of the breakers are distinctive features that make rip identification straightforward (Aagaard and Masselink, 1999). Instantaneous snapshot images were obtained during field surveys with a standard digital camera from high-ground fixed positions in each embayment, located in Fig. 1. Due to the narrow field of view of the camera used, several images were obtained sequentially with significant overlap and, when possible, mosaiced automatically using AutoStitch $($ (Brown and Lowe, 2007) to produce panoramic images of the entire embayments. The images were always acquired during low tide as the morphological expression of rip and feeder channels is amplified at this tidal stage (Brander, 1999). These were then used to identify rip and feeder channels and their locations relative to surveyed sections of the beach. Visual signatures of rip systems around the lower intertidal and shallow subtidal areas were characterized in accordance with a subjective boundary description, similar to the approach used by Brander et al. (2001). Fundamentally, incised channels and areas of reduced wave breaking were characterized as rip systems (Turner et al., 2007), while areas of intense wave breaking are associated with bars or shoals (Thornton et al, 2007). Rip systems were further divided into feeder and rip-neck channels according to the orientation of the channels. Feeder channels are generally incised alongshore or slightly obliquely, while rip-neck channels are distinctively cross-shore oriented, although not necessarily perpendicular to the shoreline or wave approach.

Besides the visual interpretation, rip and feeder channel influence on profile morphology was analysed according to patterns of morphological relief described by Brander and Cowell (2003). Rip-neck channel morphology presents sharply inflected slopes, with abrupt 
deepening (Fig. 2), that gradually become shallower in the offshore direction (Brander and Short, 2000; Brander and Cowell, 2003). Moreover, the bottom of rip channels frequently contain coarse mega-ripples (Cook, 1970), that reflect the intense sediment transport. Feeders are morphologically distinguishable by being generally alongshore-oriented (some obliquity may be present), and also because the cross-shore profile along a feeder channel generally presents a marked trough followed seaward by bar morphology (Fig. 2) (Brander and Short, 2000; Brander and Cowell, 2003; Bruneau et al., 2009).

Further indications of rip-neck and feeder channels were recorded during the surveys, performed during low tide when rip flows are higher due to tidal modulation (Brander and Short, 2000; MacMahan et al., 2006). Distinctive and strong longshore and offshore flows that could be felt while undertaking topographic surveys further enhanced recognition of feeder and rip-neck influence whenever the profiles were immediately adjacent to such channels (within a distance of approximately $20 \mathrm{~m}$ ).

Following the analysis of visual evidence and morphological patterns, along with the auxiliary indications of nearshore flows, rip-neck and feeder interaction with beach topographic profiles was classified according to three situations outlined in Fig. 2: a) profile intersected by, or immediately fronting a rip-neck channel; b) profile intersected or immediately adjacent to a feeder channel; c) profile without immediate influence of rip-neck or feeder channel. Although surveys were not performed during high-energy events but immediately after, the megarips and associated feeder channels remain as distinctive features for a significant time, as strong rip flows persist even under subsequent moderate waves (Short, 1985) and significant time is needed for morphological readjustment (McKenzie, 1958). This is particularly noticeable for rips that are topographically controlled by headlands (Gallop et al., 2011). 


\section{Figure 2}

\subsection{Offshore wave data}

231

Offshore wave data were recorded by a Datawell directional wave buoy located at Sines (Fig. 3), $65 \mathrm{~km}$ north of the study areas in a mean water depth of $97 \mathrm{~m}$. The data, composed of significant wave height, peak period and peak wave direction, were obtained from Instituto Hidrográfico. Gaps in the measured wave record ( $20 \%$ of the total record) were filled using modelled data from WANA network deepwater grid point 1044052 (Fig. 3) (Lahoz and Albiach, 2005), since significant correlation was obtained for wave height $(\rho \leq 0.001, n=$ $6137, R=0.88)$ and peak period $(\rho \leq 0.001, n=6137, R=0.61)$. Correlation analysis was also performed for the several WANA grid points along the south-western coast of Portugal to evaluate if waves at Sines were representative of the deepwater conditions further south, in locations closer to the study area (Fig. 3). The analysis provided highly significant correlation between all WANA grid points for both $H_{s o}$ and $T_{p}(\rho \leq 0.001, n=8276, R \geq 0.92)$, suggesting close similarity of wave conditions along the south-western Portuguese coast.

\section{Figure 3}

\subsection{Nearshore wave propagation}

Numerical wave modelling with SWAN (Simulating WAves Nearshore; Booij et al., 1999) was used to explore nearshore wave conditions for moderate and high-energy conditions. SWAN is an Eulerian, phase averaged, third-generation wave model that simulates the refractive propagation and evolution of the wave spectrum, and has been shown to accurately reproduce the nearshore wave field over complex bathymetries (e.g. Long and Özkan-Haller, 2005; Gorrel et al., 2011). 
SWAN was run in stationary mode, i.e. time is removed from the formulations and waves are assumed to propagate instantaneously across the modelling domain, using a nested scheme composed of three regular grids (Fig. 4). Grid resolutions of 100, 20 and $10 \mathrm{~m}$ were chosen for the large, medium and smaller grids, respectively. Model predictions were initialized on the three open boundaries of the larger grid with the parametric input from the wave buoy time series, using a JONSWAP spectral shape to represent the wave field. Input boundary conditions for the medium and small grids were determined from the computations over the large and medium grids, respectively. SWAN simulations accounted for non-linear triad wave-wave interactions, as they are rather important in shallow coastal areas (Booij et al., 1999), for bottom friction dissipation using the default variable JONSWAP expression according to Hasselmann et al. (1973) and for breaking dissipation according to the default bore-based model of Battjes and Jansen (1978). A depth-induced wave breaking parameter $(\gamma)$ of 0.78 was chosen, as this is a commonly accepted value of $\gamma$ (Ranasinghe et al., 2004), and was verified by dedicated tests on SWAN performance by Wood et al. (2001).

The nearshore wave field was computed for a range of offshore wave conditions, representing an increase from moderate to high-energy waves according to classes of $0.5 \mathrm{~m}$ from $H_{s o} \geq 0.5$ $\mathrm{m}$ to $H_{s o} \geq 7 \mathrm{~m}$. Taking into consideration the importance of storm events, different storm conditions were modelled independently. Average offshore conditions for a WNW, W and WSW storm were propagated into each embayment to investigate the combined effects of nearshore bathymetry and wave direction in the wave field using realistic conditions, while synthetic storms scenarios with constant $H_{s o}$ and $T_{p}$ of $5 \mathrm{~m}$ and $15 \mathrm{~s}$, respectively, but variable offshore wave directions ( $\mathrm{NW}, \mathrm{W}$ and $\mathrm{SW}$ ), were used to isolate the effect of incoming wave direction. Mean conditions during the January-February 2009 storm group were also modelled independently for each embayment. Breaking wave heights were obtained for $10 \mathrm{~m}$ bins alongshore for each embayment by determining the location where wave dissipation due to 
depth induced breaking becomes significant, defined as the most offshore location where a value of $1 \%$ of depth-induced breaking is reached (Harley et al., 2007).

\section{Figure 4}

\subsection{Embayment scaling parameter $\left(\delta^{\prime}\right)$}

Circulation patterns on embayed beaches were analysed parametrically using the embayment scaling parameter $\left(\delta^{\prime}\right)$ of Short (1999), which relates the embayment configuration to the incident breaking wave conditions according to Eq. (1).

$\delta^{\prime}=S^{2} / 100 C_{l} H_{b}$

where $S$ is the embayment shoreline length, $C_{l}$ is the embayment width (distance between headlands), and $H_{b}$ is the breaking wave height. This empirical approximation was derived from unpublished work by Martens and collaborators on morphometric analysis of embayed beaches, and presented by Short (1996) and Short and Masselink (1999). The selection of this formula was based on the findings of Short $(1999 ; 2010)$, who indicated that the degree of headland impact on surf zone circulation and, consequently, circulation type in embayed beaches can be predicted using $\delta^{\prime}$. When $\delta^{\prime}>19$, the impact of headlands is limited and normal surfzone circulation operates along the embayment, similar to what would be expected for unconstrained sandy beaches. As $\delta$ ' ranges between 19 and 8, transitional circulation prevails with headlands increasingly influencing surfzone circulation. Rip currents increase in size and reduce in number and become progressively topographically-controlled. Fully cellular circulation develops when $\delta^{\prime}<8$, and topography controls the surfzone circulation, dominated by strong longshore flows that feed on one to two megarips draining the entire embayment (Short, 1999; 2010). Following Short (1999, 2010), calculations of $\delta$ 'were performed considering a typical surfzone gradient of 0.01 for each embayment. This is 
considered representative of dissipative environments such as those in this study. Values of $H_{b}$ were obtained from alongshore averaged SWAN simulation results and the embayment configuration parameters $S$ and $C_{l}$ were obtained from GIS-based digital orthophotography analysis.

\section{Results}

\subsection{Wave conditions}

High-energy events were concentrated between October and April, while during the remaining months wave conditions were less energetic, although $H_{s o}$ frequently exceeded $2 \mathrm{~m}$ (Fig. 5). Storm waves were mostly from WNW-NW directions, reflecting the storm climate of the southwestern coast of Portugal (82\% of storms between 1988 and 2008 were from a WNW-NW direction (Costa and Esteves, 2010)). There were, however, two occasions when WSW storm waves impacted the coast (April 2008 and February 2009). This occurred for only a few hours, and was followed immediately by WNW waves that obliterated the effects of WSW storm waves on the beaches.

\section{Figure 5}

Grouping of high-energy events was frequent, even though the storm threshold $\left(H_{s o}>5 \mathrm{~m}\right)$ was not reached in every single event (e.g. April 2008). If lower storm thresholds were considered, such as those proposed by Costa et al. (2001) $\left(H_{s o}>4.5 \mathrm{~m}\right)$ or Costa and Esteves (2010) $\left(H_{s o}>3.5 \mathrm{~m}\right.$ for at least 12 hours with maximum $H_{s o}$ reaching $\left.4.5 \mathrm{~m}\right)$, more highenergy events would be classified as storms and storm groups. Nevertheless, the most significant events during the monitoring period (dark grey in Fig. 5) were a single storm in early January 2008, with $H_{s o}$ reaching $8 \mathrm{~m}$ and wave heights in excess of $5 \mathrm{~m}$ for 36 hours, 
and a group of 5 consecutive storms between mid January and early February 2009. This storm group, with storm peaks in the $16^{\text {th }}, 20^{\text {th }}$ and $25^{\text {th }}$ January and $01^{\text {st }}$ and $05^{\text {th }}$ of February 2009 , represented a period of continuously high waves for 22 days with maximum $H_{s o}$ of 6.7 $\mathrm{m}$. Averaged over the entire storm group duration, $H_{s o}$ was $4.5 \mathrm{~m}$ and $T_{p} 14.5 \mathrm{~s}$ from a westnorthwesterly direction $\left(300^{\circ}\right)$.

\subsection{Morphological change}

Time series of profile volume above MLWS level are presented in combination with the classification of rip system interaction with the cross-shore beach profiles for each embayment (Fig. 6 to 8 ).

\subsubsection{Arrifana}

At Arrifana erosion-dominated periods occurred during high waves, and were associated with the development of feeder and rip-neck channels intersecting or in the vicinity of the profiles (Fig. 6). From late November to early December 2007, following an increase in wave heights with grouping of high-energy events, average profile erosion of $27 \mathrm{~m}^{3} / \mathrm{m}$ occurred, with the development of feeder channels adjacent to Arrifana north and south profiles. With the onset of the early January 2008 extreme storm, a further $62 \mathrm{~m}^{3} / \mathrm{m}$ where eroded on average in Arrifana beach profiles by mid January 2008. This was accompanied by the development of rip systems in the extremities of the beach, with feeder channels intersecting both the central and southern profiles (while a rip was present in the northern section of the beach, it was located more than $20 \mathrm{~m}$ north of the profile location). The storm induced erosion was followed by gradual beach recovery, although without complete infilling of the rip systems. Alongshore migration of the southern rip-neck channel, which had already intersected the south profile by the time of the March 2008 survey, was associated with beach accretion, as 
this rip was already significantly infilled. The recovery process was interrupted in mid-April by a group of two storms, which reactivated the erosional conditions in the southern rip system and promoted the development of another rip system in the northern section of the beach. Significant recovery took place during the following months at Arrifana beach, as the rip-neck and feeder channels become infilled, allowing onshore displacement of sand from the intertidal to the subaerial beach.

Erosive conditions resumed by December 2008, with development of rip system circulation across the entire embayment. It was, however, with the onset of the January-February 2009 storm group that most abrupt changes occurred, with generalized erosion at Arrifana beach, particularly noticeable on the north and south profiles. Erosion of $117 \mathrm{~m}^{3} / \mathrm{m}$ and $98 \mathrm{~m}^{3} / \mathrm{m}$ in the north and south profiles, respectively, was associated with the development of rip-neck channels intersecting profile location, while at the central profile the development of a feeder channel resulted in moderate erosion $\left(20 \mathrm{~m}^{3} / \mathrm{m}\right)$. Although all profiles at Arrifana recovered significantly during the 7 months following the January-February 2009 storm group (Fig. 6), it was mostly after the rip-neck and feeder channels become infilled under lower waves that volumetric change increased substantially.

\section{Figure 6}

\subsubsection{Mt. Clérigo}

During the first year of monitoring, beach profiles at Mt.Clérigo showed similar variation to that of Arrifana. Erosion dominated the period between late November 2007 and April 2008, followed by accretion until mid-November 2008 (Fig. 7). During the erosion-dominated period, the lowest volumes attained in the northern and central profiles, in April and March 2008, respectively, were associated with the development of a large-scale rip system, whose 
rip-neck channel was initially located in the centre of the beach and then migrated northwards. Although no rip-neck or feeder channel could be identified adjacent to the southern profile (Fig. 7), erosion at Mt. Clérigo during the first year of monitoring reached its maximum in this profile with the removal of $122 \mathrm{~m}^{3} / \mathrm{m}$ of sediment in relation to the initial profile volume. Between November 2008 and early April 2009, a second erosion-dominated period associated with high waves and storm grouping resulted in extreme erosion throughout the entire Mt. Clérigo embayment. Average erosion of $98 \mathrm{~m}^{3} / \mathrm{m}$ for Mt. Clérigo beach profiles marked the initial phase of this erosion-dominated period, which lasted until early January 2009. During this initial phase no rip-neck or feeder channels developed in the vicinity of the south profile, while feeder channels interacted with the centre and north profiles. The second phase of erosion, between early January and early April 2009, occurred in close association with the January-February 2009 storm group (Fig. 7). On average, this second phase led to a further $196 \mathrm{~m}^{3} / \mathrm{m}$ of sand being removed from the profiles, with most of the erosion concentrated during the storm group (average erosion of $167 \mathrm{~m}^{3} / \mathrm{m}$ between 11/01/2009 and 09/02/2009). The extreme erosion during the storm group was accompanied by the development of a wide megarip in the centre of the beach, with a rip-neck channel intersecting the lower intertidal section of the central profile. Connected to it, feeder channels from both sides of the beach intersected the southern and northern profiles. Beach recovery was initiated in late April for all three profiles but even after 5 months the volume restored to the beach was significantly lower than what was removed between November 2008 and early April 2009 (on average recovery only reached $21 \%$ of the eroded volume). Notably, during the recovery period, the central rip-neck channel and the northern feeder channel were still active, hindering significant recovery, while sediment accretion on the southern profile was only initiated after April 2009, once the feeder channel had been infilled (Fig. 7). 


\subsubsection{Amoreira}

406

407

Beach profile response to high-energy events at Amoreira beach was variable during the first year of monitoring, although the association between rip-neck or feeder channels and erosiondominated periods was still clearly recognized (Fig. 8). Significant erosion on central and southern profiles occurred immediately in response to December 2007 energetic waves group (three events with $H_{s o}$ around $4 \mathrm{~m}$ in 15 days), and the early January 2008 extreme storm. This later erosional event was accompanied by the development of a rip system with feeder channels interacting with the central and southern profiles. Eroded volumes reached $148 \mathrm{~m}^{3} / \mathrm{m}$ in the southern profile and $110 \mathrm{~m}^{3} / \mathrm{m}$ in the central profile, but only $13 \mathrm{~m}^{3} / \mathrm{m}$ in the northern profile. However, following a northward displacement of the rip system in the subsequent months, $213 \mathrm{~m}^{3} / \mathrm{m}$ of sand were removed from the north profile. Recovery from this erosive period took as much as 7 to 9 months, although it did not proceed linearly in the central and southern profiles, occurring subsequent to the infilling of rip-neck and feeder channels. Under the action of the January-February 2009 storm group, severe erosion occurred in the northern and central profiles (Fig. 8), while the south profile only experienced moderate erosion. Maximum erosion of $268 \mathrm{~m}^{3} / \mathrm{m}$ was registered in the central profile, closely followed by the northern profile with an eroded volume of $243 \mathrm{~m}^{3} / \mathrm{m}$. During this storm group a wide megarip developed in the centre of the beach, with a rip-neck channel intersecting the central profile. This was directly connected to a deep feeder channel in the northern section. Both features persisted for several months, hindering beach recovery in the northern and central profiles (Fig. 8).

\section{Figure 8}


In the absence of hydrodynamic measurements in the shoaling and surfzone of the three

431

432 embayments studied, particularly during moderate and high-energy events that drive most significant morphological changes, numerical wave modelling was used for simulation of nearshore wave field. Breaking wave heights were obtained for increasing offshore wave conditions (Table 1), real and synthetic storms (Table 2 and Fig. 9) and also for the average conditions during the January-February 2009 storm group (Fig. 10).

\section{Table 1}

\section{Table 2}

Model results highlight the sensitivity of the alongshore variation in nearshore wave heights to the offshore bathymetry in Arrifana embayment, while Mt. Clérigo and Amoreira present fairly alongshore uniform conditions. Modelled breaking wave heights indicate that for Mt. Clérigo and Amoreira beaches, which are directly exposed to the dominant north-westerly waves, alongshore variation in breaking wave height is almost negligible, as evidenced for standard deviation values below 0.1 in all simulations (Table 1). On these two beaches, breaking wave height is on average equivalent to the offshore wave height, with most variation within a difference range of $10 \%$. Arrifana beach, conversely, shows considerable alongshore variation and important reductions in breaking wave height comparing to the offshore counterpart (Fig. 9 and Table 1). The northern section of the beach experiences breaker heights up to $3.5 \mathrm{~m}$ lower than the southern section, during the most extreme conditions when $H_{s o} \geq 7 \mathrm{~m}$. This alongshore gradient, which increases concurrently to 
offshore wave height as evidenced by increasing standard deviation values (Table 1), is due to the sheltering effect of the prominent northern headland, which forces the diffraction of the dominant west-northwesterly waves. Wave diffraction, together with refraction and attenuation on a gentle shoreface (average $\tan \beta$ of 0.02 ), induces breaking wave heights on average $35 \%$ lower than the offshore wave height, but ranging between $60 \%$ and $20 \%$ lower on the northern and southern sectors, respectively.

\section{Figure 9}

The nearshore wave conditions during storms, both the observed and synthetic events (Fig. 9 and Fig. 10), reflect, in general, the alongshore gradients identified in Arrifana embayment, while highlighting higher sensitivity of Mt. Clérigo and Amoreira embayments to changes in incoming wave direction. For synthetic storms, where only wave direction has been modified, Arrifana embayment maintains significant alongshore gradients, but these are quite insensitive to the variation in wave direction, with the centre of the embayment presenting similar conditions for NW, W and SW storms (Fig. 9). Considering both the real storms (Table 2) and synthetic storms, breaking wave conditions calculated for Mt. Clérigo and Amoreira embayments are similar, not only in height, but also alongshore uniformity (Fig. 9 and Fig. 10). In these two embayments offshore regular bathymetry precludes noticeable alongshore variations, but their orientation does enhance the attenuation of real WSW and synthetic SW stormy waves, with modelled breaking wave heights being reduced by up to 1.5 m.

\section{Figure 10}


479 Parametric analysis of embayment circulation was performed for the modal wave conditions and also for the range of modelled breaking wave heights presented in Table 1, using the formulation for the embayment scaling parameter $\left(\delta^{\prime}\right)$ described in Eq. (1). The computed values of $\delta$ ' place Arrifana as an embayment modally subjected to normal circulation, owing to significant length and moderate breaking wave heights (Table 3 ). Computing $\delta$ ' for the range of alongshore averaged modelled breaking wave heights in Arrifana, the wave-driven circulation becomes transitional as $H_{b}$ approaches $2 \mathrm{~m}$, and cellular circulation is established when $H_{b}$ overcomes $3.5 \mathrm{~m}$ (Fig. 11).

\section{Table 3}

\section{Figure 11}

Mt. Clérigo and Amoreira embayments evidence similar wave conditions, as presented in the nearshore wave modelling (Section 4.3), and the geometric characteristics of these two embayments are also similar, as both have reduced widths and lengths. Therefore, the combination of small dimensions along with similar exposure to more energetic conditions renders both beaches modally cellular (Table 3). Transitional circulation is approached in both embayments when $H_{b}$ reduces to values below $1.5 \mathrm{~m}$ (Fig. 11), while normal circulation occurs very infrequently $\left(H_{b}<0.5 \mathrm{~m}\right)$. Although a $\delta$ ' value of 7 places Mt. Clérigo and Amoreira embayments in a modally cellular circulation type, such a value is very close to the threshold for transitional circulation (defined as $\delta^{\prime} \geq 8$ ), implying that sustained conditions of cellular circulation in both embayments are only established once $H_{b}$ exceeds $2 \mathrm{~m}$ (Fig. 11). 


\section{Discussion}

\subsection{Megarips or large rips?}

The results presented in this study highlight the role of megarips in the periodic erosion of sand from high-energy embayed beaches, providing new insights into their cumulative action during and after storm groups. While significant progress has been made recently in the study of the hydrodynamics and morphodynamic coupling of rip systems, particularly by field experiments (e.g. Brander and Short, 2000; MacMahan et al., 2005; Bruneau et al., 2009; Austin et al., 2010), such efforts have concentrated on open coast rips. Conceptually, despite their large dimensions and association with moderate to high wave conditions, those are largescale accretionary rips associated with downstate transitions in intermediate beaches and are consequently quite different to topographic rips or megarips (Brander and Short, 2000; Short, 2007; MacMahan et al., 2010). The rip systems described here differ from such large-scale accretion rips because they develop during high-energy events (Fig. 12), when the beaches would otherwise have transitioned upstate to dissipative conditions, characterized by the absence of rip circulation (Wright and Short, 1984). Their location and development is also controlled by embayment configuration, which places then conceptually as topographic rips, transitioning to megarips under high-energy conditions and dominating the circulation of entire embayments (Short, 2010).

\section{Figure 12}

The reduced dimension of the embayments studied, combined with exposure to an energetic wave climate, contributes to circulation types influenced by embayment topography almost permanently, as indicated by the embayment scaling parameter $\left(\delta^{\prime}\right)$. Despite conditions for transitional or cellular circulation may be maintained for most of the wave conditions 
encountered in Arrifana, Mt. Clérigo and Amoreira, the actual transition for megarip circulation only occurs during high waves. A breaking wave height $\left(H_{b}\right)$ of $3 \mathrm{~m}$ was proposed by Short $(1985,2010)$ as a threshold for the transition to megarip circulation, considering that when $H_{b}$ exceeds this value fully dissipative conditions would prevail (Wright and Short, 1984). While detailed validation of this threshold cannot be presented, analysis of the variation of $\delta$ ' for increasing wave heights (Fig. 11), suggests that when $H_{b}$ reaches $3.5 \mathrm{~m}$ conditions for cellular circulation are established for all embayments. The beaches studied are modally intermediate to dissipative in state, and observations confirm that as $H_{b}$ increases to more than $3 \mathrm{~m}$ dissipative surfzones prevail, with megarips dominating the surfzone circulation in Arrifana, Mt. Clérigo and Amoreira. When wave conditions decrease, these rip systems do not cease functioning. They, however, maintain roughly the same position, not experiencing significant alongshore migration as observed for accretionary/erosional rips (e.g. Holman et al., 2006; Turner et al., 2007; Orzech et al., 2010). This occurs because they remain topographically controlled, downgrading from megarips to large-scale topographic rips.

\subsection{Megarip development}

Temporal and spatial changes in wave breaking drive variations in wave set-up/down, producing pressure gradients that induce water-flow from areas of high waves towards areas of low waves, where flow convergence creates a constrained jet-like flow that exits the surf zone as a rip current (Bowen, 1969; MacMahan et al., 2006; Dalrymple et al., 2011).

Topographic rips and megarips share this same forcing mechanism, but while most rips are driven by longshore variations in wave height due to bathymetric variation generally associated with rhythmic shoals and channels in intermediate beaches (Aagaard and Masselink, 1999), and less frequently with wave-wave interactions (MacMahan et al., 2006), 
553

554

555

556

557

558

559

560

561

562

563

564

565

566

567

568

569

570

571

572 Development of a second megarip in a southern location, adjacent to the southern profile at

573 Arrifana beach, cannot be derived from modelled alongshore variations in breaker height

574 alone. However, there is a tendency for megarip development adjacent to headlands (as a

575 contour current) exposed to an obliquely incident wave field (Coutts-Smith, 2004; Short,

576

577

topographic rips and megarips result from longshore variations in wave height due to attenuation and refraction around offshore topographic features like headlands and reefs (Short, 1985).

Alongshore variations in breaking wave height assessed using numerical wave modelling for Arrifana beach are consistent with the development of a megarip in the more protected northern sector (Fig. 13). The sheltering effect of the northern headland creates a geometric shadow, leading to an area of significantly lower breakers on the northern sector (Fig. 10), inducing an alongshore flow towards the northern headland. The position of this megarip endorses the suggestion that under extreme conditions with oblique incident waves, a wave setup-driven mechanism would be responsible for the development of a megarip in the protected end of an embayment (Coutts-Smith, 2004), similar to re-circulation cells present in the lee of groynes, as recently demonstrated by Pattiaratchi et al. (2009). Due to nearshore bathymetry and convergence of breaking waves with the circulation cell, the northern megarip is deflected obliquely towards the centre of the embayment, instead of flowing straight offshore. It then develops an alongshore component, visible in the rip-head plume (Fig. 12), restricting the seaward extent of the northern megarip.

\section{Figure 13}

$$
\text { contour current) exposed to an obliquely incident wave field (Coutts-Smith, 2004, Short, }
$$
2010), just as a rip system develops in the updrift side of a groyne or structure (Pattiaratchi et al., 2009; Dalrymple et al., 2011). Driven by oblique waves, an alongshore current runs 
parallel to the beach and is forced to turn seaward against the downdrift headland. Lateral positioning of the southern megarip at Arrifana supports this hypothesis, due to the occurrence of obliquely incident waves. Despite the reduced extension of the southern headland, the beach is bounded by submerged rocky outcrops approximately $100 \mathrm{~m}$ southwards of profile south, which force the alongshore current to deflect offshore, forming the distinctive southern megarip (Fig. 13). A divergence zone, separating the alongshore currents feeding both the northern and southern megarips, is located in the centre of the embayment, as evidenced by the post-storm snapshot in Fig. 12. The location of a divergence zone in the alongshore currents is associated with changes in the alongshore gradient in wave height due to topographic sheltering (Pattiaratchi et al., 2009). Breaking wave heights obtained from wave modelling confirm that the centre of Arrifana embayment evidences more constant wave conditions, with intermediate heights between the lower waves in the northern section and the higher waves in the southern section (Fig. 9).

Megarips have also been noted in the centre of longer embayments ( $>1-2 \mathrm{~km})$, associated with shore normal incident waves (Short, 1985; Short, 2010). Although Mt. Clérigo and Amoreira are significantly shorter than this (approximately $600 \mathrm{~m}$ ), both beaches are normally exposed to the energetic north-westerly waves. During high-energy events, one megarip developed roughly on the centre of each embayment, occasionally extending to the northern sectors of both beaches (Fig. 14 and Fig. 15). The absence of noteworthy alongshore variation in modelled breaking wave height at Mt. Clérigo and Amoreira (Fig. 9 and Fig. 10), provide no immediate explanation for megarip development due to breaker gradients at these beaches. However, development of megarips in the centre of embayed beaches has been shown to occur during storms (Wright et al., 1979; Short, 1985), and recent analytical modelling approaches by Silva et al. (2010) suggest development of cellular circulation with a rip developing in the centre of embayed beaches under normal incident waves. Such rip 
603

604

605

606

607

608

609

610

611

612

613

614

615

616

617

618

619

620

621

622

623

624

625

626

627

circulation is related to embayment geometry influencing the nearshore wave field, particularly breaker height and wave obliquity at breaking, as suggested by Huntley et al. (1988) and confirmed numerically by Silva et al. (2010). While obtained for low to moderate wave conditions, the results of Silva et al. (2010) provide a hypothesis for the initial development of an embayment scale rip circulation system. Under increasing wave heights this circulation system would transition into a megarip since, as suggested by the authors, once the circulation is established, wave height variation would only strengthen or weaken the current velocities without modifying the circulation patterns.

At Mt. Clérigo, nearshore topographic control is likely to also influence the development and location of a megarip in the centre of the embayment, as a rocky outcrop in the lower intertidal and subtidal zone extends obliquely from the south to the centre of the beach (Fig. 14). This outcrop provides a permanent barrier that forces longshore currents to flow seaward, as reported elsewhere by Davidson-Arnott (2010), scouring a channel that widens to a large megarip during high-energy events.

\section{Figure 14}

Apart from the Arrifana megarips, where conditions for alongshore variation in breaker height inducing pressure gradients are maintained due to topographic sheltering, no other megarip could be inferred from wave modelling results. All models of rip circulation are forced by alongshore variations in wave height (MacMahan et al., 2006), and under homogeneous alongshore contours, as observed for Amoreira and M. Clérigo embayments, such variations are not expected to be significant. Nonetheless, as evidenced in previous studies, even small bathymetric irregularities can influence surfzone hydrodynamics, inducing wave gradientdriven rip circulations (Calvete et al., 2007; MacMahan et al., 2008; Dalrymple et al., 2011). 
Figure 15

630

\subsection{Enhanced erosion by megarips and storm grouping}

632

Localized beach and dune erosion has been associated to the coupling between rhythmic cuspate shorelines and rip currents in long embayments (Thornton et al., 2007). Along highly compartmentalized coastlines, with small and bedrock-bounded embayed beaches, cellular circulation, and particularly megarips, has also been presented as a major mechanism of beach erosion (Short, 1985), while undertow has been found to be of reduced efficiency in crossshore sediment transport (Dehouck et al., 2009). Destructive effects and erosive hazards may be greatly enhanced by the action of megarips (Wright, 1981), especially because of their ability to transport sediment, flushing entire beach compartments through their wide and deep feeder systems and intense rip flows (Short, 1979; Wright, 1981). Most severe beach erosion occurs in the lee of megarips (Short, 1985), and for profiles at Arrifana south, Mt. Clérigo centre and Amoreira centre, where megarip development was more frequent, erosion was generally higher than in the remaining profiles. Profiles intersecting or adjacent to feeder channels draining to the main rip also experienced enhanced erosion, as evidenced in profiles Mt. Clérigo north and south and Amoreira north. In contrast, Amoreira southern and Arrifana central profiles presented lower variation, being also less regularly associated with either ripneck or feeder channels (Fig. 6 and Fig. 8).

The coupling of rip-neck and feeder channels with enhanced erosion of Arrifana, Mt. Clérigo and Amoreira beach profiles is noticeable during individual high-energy events, although the relationship is not always immediate or linear since morphodynamic response is influenced by antecedent conditions, requiring an adjustment time (Wright and Short, 1984). Nevertheless, under the action of the January-February 2009 storm group the relationship is remarkable. 
653

654

655

656

657

658

659

660

661

662

663

664

665

666

667

668

669

670

671

672

673

674

675

676

677

Storm groups, or sequences of storms without significant recovery in between (Ferreira, 2006), have long been recognized as an important mechanism for extreme erosion of embayed beaches (Thom, 1974), driving dramatic shoreline retreat on erosion hotspots (Smith et al., 2010), or triggering erosion dominated periods of several years (Thom and Hall, 1991).

Considering that the most significant beach cut on short embayed beaches is produced by megarips (Wright, 1981), their maintenance during storm groups would be expected to produce extreme and continued erosion. Our results provide field evidence of this process. All profiles were influenced by megarips during the January-February 2009 storm group, either by rip-neck or feeder channels, inducing widespread beach erosion. Except for profiles Arrifana centre, located in a divergence zone where feeder channel influence was tangential, and Amoreira south where feeder influence was short-lived, all profiles were severely eroded. This storm group clearly demonstrated the spatial extent of megarips and confirmed their ability to dominate the circulation of entire embayments. Moreover, the persistence of megarip action during the storm group led to the development of large and deep rip-neck and feeder channels (Fig. 12), which required a significant post-storm period to be infilled. Rip currents remained active for a long period, as they were coupled to the underlying morphology, and caused continued erosion.

\subsection{Implications for beach recovery}

Seaward transport of sediment is greatly enhanced by megarips, which are considered to be responsible for sediment exchange between embayed beaches and the nearshore or even the inner-shelf (Short, 1985; Coutts-Smith, 2004). Sediment removed from the beach by megarips has been shown to be deposited at depths of 10-25 m (Coutts-Smith, 2004; Smith et al., 2010), owing to seaward extensions of approximately 1.5 to 4 times the surfzone width (CouttsSmith, 2004; Dalrymple et al., 2011), or between 1 and 2 km (Short, 2010). Sand withdrawn 
678 from Arrifana, Mt. Clérigo and Amoreira beaches by megarips was presumably transported to 679 depths between 10 to $15 \mathrm{~m}$, based on schematic mapping (Fig. 13 to 15), and spread out on 680 the lower shoreface, as observed elsewhere by Coutts-Smith (2004) and Smith et al. (2010), 681 resulting in net loss of sediment from beaches. There were however, significant differences 682 between the study beaches. These can be explained by differences in wave forcing, since 683 increase in incident wave height is associated with higher rip current speeds (Pattiarachi et al, 2009; Dalrymple et al., 2011), and also a higher offshore extent of megarips (Coutts-Smith, 2004). On Mt. Clérigo and Amoreira beaches, due to normal exposure to incident storm

686

687 waves, which break without considerable attenuation driving either stronger or/and seaward extended megarip flows, a higher volume of sand was lost and apparently to greater depths, as materialized by the inability of both beaches to recover in the following months. On Arrifana beach, where breaking wave heights are consistently lower, net volumetric loss was reduced, although severe erosion occurred during the January-February 2009 storm group.

During storm groups, sediment lost from the beach and the upper shoreface is expected to be even greater than for single storm events (Cowell et al., 1999), due to inability to reach a storm equilibrium profile during storm groups (Inman et al., 1993) and continued conditions for megarip-driven erosion as a result of coastal disequilibrium (Smith et al., 2010). While megarips developed during the first year of monitoring caused moderate erosion, even with the January 2008 extreme single storm, no significant net volumetric loss was observed. In contrast, erosion associated with the January-February 2009 storm group was significant, probably associated with substantial export of sediment to the nearshore, promoted by the long duration of the event.

Once formed, and being topographically forced, large rips can persist in the same location for extended periods (Short, 1985), evidencing a much longer lag-time in their response to changing wave conditions (Gallop et al., 2011). Owing to positive morphodynamic feedback, 
alongshore gradients are maintained and eventually enforced. Rip-neck and feeder channels continue then to flush and erode sediment, resulting in stable circulation patterns which have been observed to persist for several years in the case of rips controlled by headlands (Gallop et al., 2011). Considerable time is then needed for readjustment after megarip-induced erosion (McKenzie, 1958), and complete recovery can require several years (Wright and Short, 1983). Since high-energy conditions were maintained throughout the January-February 2009 storm group, megarip circulation was continuously active for at least 22 days, creating large and deep channels. Consequently, rip-neck and feeder channel influence on beach profiles was not only intense but also persistent. Beach recovery has been significantly inhibited, except for Arrifana beach, and channel infilling has been occurring slowly, mostly due to onshore and lateral expansion of subtidal and lower intertidal shoals. Once the channels become infilled a faster recovery is expected, as evidenced in Arrifana beach. The enhanced ability of Arrifana beach to recover after the storm group suggests that sediment taken from the beach remained at shallower depths, within the constrained environment of the embayment, and was available for subsequent rip and feeder channel infilling allowing beach recovery, most likely because megarips at Arrifana were less intense and/or extensive.

\section{Conclusion}

Morphological change in three embayed beaches along the high-energy south-western coast of Portugal was monitored over two years. During this period, profile erosion has been mostly related to the development of megarips and associated rip-neck and feeder channels.

Differences within and between beaches were related to embayment geometry and orientation. On short beaches normally exposed to incident storm waves (Mt. Clérigo and Amoreira), a single megarip developed in the centre of each embayment, while obliquely incident waves were associated with the development of two megarips in both extremities of 
Arrifana embayment, driven by marked alongshore gradients in breaking wave height and interaction with embayment boundaries.

On the three embayed beaches studied, moderate erosion was observed during individual storms, and more importantly, extreme erosion occurred when megarips persisted for several weeks during the action of a storm group. Net sediment loss in the more exposed Mt. Clérigo and Amoreira beaches suggests sand export to the lower shoreface, driven by the persistent action of megarips during the storm group. While megarips have long been recognized as an important mechanism of embayed beach erosion, their continued and enhanced action during storm groups has only now been demonstrated, providing a clear connection between megarips and storm groups in the extreme erosion of embayed beaches. This study also demonstrates that the maintenance of a rip circulation pattern after storms (or storm groups), enforced by morphodynamic feedback, reduces beach recovery ability until the rip-neck and feeder channels are infilled.

Comprehensive field measurements of megarips have yet to be accomplished (e.g. including measurements of surfzone hydrodynamics and nearshore bathymetric change driven by megarips), and this study does not fill such gap. However, by relating megarip influence to profile variation and analysing modelled and parametric indications of megarip location, the present work provides new insights into the conditions that drive megarip development and the role of megarips in the erosion and recovery of embayed beaches.

\section{Acknowledgements}

We gratefully acknowledge the help of everyone involved in the fieldwork data collection, especially at dawn during cold winter stormy days. Thanks also to Rui Taborda, Guillaume Dodet and Xavier Bertin for providing initial training with SWAN, and Derek Jackson for discussion of modelling aspects. Mara Nunes and Thomas Smyth suggested improvements to 
753

754

755

756

757

758

759

760

761

762

763

764

765

766

767

768

769

770

771

772

773

774

775

776

early versions of the manuscript. This work is a contribution to BAYBEACH project

(Evolution and Management of Embayed Beaches in Contrasting Environments) funded by

FCT under contract PTDC/CTE-GEX/66893/2006. Carlos Loureiro was supported by FCT, grant reference SFRH/BD/27878/2006. Hydrodynamic data from Sines buoy were provided by Instituto Hidrográfico. Modelled WANA wave data were kindly supplied by Puertos del Estado.

\section{References}

Aagaard, T., Masselink, G., 1999. The surf zone. In: Short, A.D. (Ed.), Handbook of Beach and Shoreface Morphodynamics. John Wiley \& Sons, Chichester, pp. 71-118.

Almeida, L.P., Ferreira, Ó., Pacheco, A., 2011. Thresholds for morphological changes on na exposed sandy beach as a function of wave height. Earth Surface Processes and Landforms, 36 (4), 523-532.

Austin, M., Scott, T., Brown, J., Brown, J., MacMahan, J., Masselink, G., Russel, P., 2010. Temporal observations of rip current circulation on a macro-tidal beach. Continental Shelf Research, 30 (9), 1149-1165.

Battjes, J.A., Janssen, J.P.F.M., 1978. Energy loss and set-up due to breaking of random waves. Proceedings of the 16th International Conference on Coastal Engineering. ASCE, New York, USA, pp. 569-587.

Booij, N., Ris, R.C., Holthuijsen, L.H., 1999. A third-generation wave model for coastal regions - 1. Model description and validation. Journal of Geophysical Research, 104 (C4), 7649-7666.

Bowen, A.J., 1969. Rip Currents 1. Theoretical Investigations. Journal of Geophysical Research, 74 (23), 5467-5478. 
Brander, R.W., 1999. Field observations on the morphodynamic evolution of a low-energy rip current system. Marine Geology, 157 (3-4), 199-217.

Brander, R.W., Short, A.D., 2000. Morphodynamics of a large-scale rip current system at Muriwai Beach, New Zealand. Marine Geology, 165 (1-4), 27-39.

Brander, R.W., Cowell, P.J., 2003. A trend-surface technique for discrimination of surf-zone morphology: rip current channels. Earth Surface Processes and Landforms, 28 (8), 905-918.

Brander, R.W., Cowell, P.J., Short, A.D., 2001. Morphometric approaches to describing rip current behaviour. Journal of Coastal Research, SI 34, 128-137.

Brown, M., Lowe, D., 2007. Automatic panoramic image stitching using invariant features. International Journal of Computer Vision, 74 (1), 59-73.

Bruneau, N., Castelle, B., Bonneton, P., Pedreros, R., Almar, R., Bonneton, N., Bretle, P., Parisot, J.P., Sénéchal, N., 2009. Field observations of an evolving rip current on a meso-macrotidal well-developed inner bar and rip morphology. Continental Shelf Research, 29 (14), 1650-1662.

Callaghan, D.P., Nielsen, P., Short, A.D., Ranashinge, R., 2008. Statistical simulation of wave climate and extreme beach erosion. Coastal Engineering, 55 (5), 375-390.

Calvete, D., Coco, G., Falqués, A., Dodd, N., 2007. (Un)predictability in rip channel systems. Geophysical Research Letters, 34, L05605.

Cook, D.O., 1970. Occurence and geologic work of rip currents off southern California. Marine Geology, 9 (3), 173-186.

Costa, M., Esteves, R., 2010. Clima de agitação marítima na costa oeste de Portugal Continental. Proceedings of XI Jornadas Técnicas de Engenharia Naval - O Sector Marítimo Português. Edições Salamandra, Lisboa, Portugal. 413-426. 
Costa, M., Silva, R., Vitorino, J., 2001. Contribuição para o estudo do clima de agitação marítima na costa Portuguesa. Proceedings of 2as Jornadas de Engenharia Costeira e Portuária. AIPCN, Aveiro, Portugal, 20 p. (CD-ROM).

Coutts-Smith, A., 2004. The significance of mega-rips along an embayed coastline. Ph.D. Thesis, University of Sydney, Australia.

Cowell, P.J., Hanslow, D.J., Meleo, J.F., 1999. The Shoreface. In: Short, A.D. (Ed.), Handbook of Beach and Shoreface Morphodynamics. John Wiley \& Sons, Chichester, pp. 39-71.

Dalrymple, R.A., MacMahan, J.H., Reniers, A.J.H.M., Nelko, V., 2011. Rip currents. Annual Review of Fluid Mechanics, 43, 551-581.

Davidson-Arnott, R., 2010. Introduction to Coastal Processes and Geomorphology. Cambridge University Press, Cambridge.

Dehouck, A., Dupuis, H., Sénéchal, N., 2009. Pocket beach hydrodynamics: the example of four macrotidal beaches, Brittany, France. Marine Geology, 266 (1-4), 1-17.

Evans, P., Hanslow, D., Coutts-Smith, A., You, Z., 2000. Nearshore-Inner Shelf Sediment Exchange on the NSW Central Coast. Proceedings of the 27th International Conference on Coastal Engineering. ASCE, Sydney, Australia, pp. 3151-3164.

Ferreira, Ó., 2005. Storm groups versus extreme single storms: predicted erosion and management consequences. Journal of Coastal Research, SI 42, 221-227.

Ferreira, Ó., 2006. The role of storm groups in the erosion of sandy coasts. Earth Surface Processes and Landforms, 31 (8), 1058-1060.

Freire, P., Taborda, R., Bertin, X., Guerreiro, M., Fortunato, A.B., Silva, A.M., Andrade, C., Oliveira, A., Antunes, C., Freitas, M.C., Nahon, A., Rodrigues, M., Bruneau, N., 2011. Medium-term morphodynamic evolution of a small coastal inlet. Journal of Coastal Research, SI 64, 666-670. 
Gallop, S.L., Bryan, K.R., Coco, G., Stephens, S.A., 2011. Storm-driven changes in rip channel patterns on an embayed beach. Geomorphology, 127 (3-4), 179-188.

Gorrel, L., Raubenheimer, B., Elgar, A., Guza, R.T., 2011. SWAN predictions of waves observed in shallow water offshore of complex bathymetry. Coastal Engineering, 58 (6), 510-516.

Harley, M.D., Turner, I.L., Morris, B.D., Short, A.D., Ranasinghe, R., 2007. Nearshore wave climate and localised erosion during high wave events - SE Asutralia. Proceedings of the 18th Australasian Coastal and Ocean Engineering Conference. IEAust, Melbourne, Australia. No. 89 (CD-ROM).

Hasselman, K., Barnett, T.P., Bows, E., Carlson, H., Cartwright, D.E., Enke, K., Ewing, J.A., Gienapp, H., Hasselman, D.E., Kruseman, P., Meerburg, A., Müller, P., Olbers, D.J., Richter, K., Sell, W., Walden, H., 1973. Measurements of wind-wave growth and swell decay during the Joint North Sea Wave Project (JONSWAP). Ergänzungsheft zur Deutschen Hydrographischen Zeitschrift, A8 (12), pp. 1-95.

Holman, R., Symonds, G., Thornton, E.B., Ranasinghe, R., 2006. Rip spacing and persistence on and embayed beach. Journal of Geophysical Research, 111, C01006.

Holthuijsen, L.H., 2007. Waves in Oceanic and Coastal Waters. Cambridge University Press, Cambridge.

Huntley, D.A., Hendry, M.D., Jaines, J., Greenidge B., 1988. Waves and rip currents on a Caribbean pocket beach, Jamaica. Journal of Coastal Research, 4 (1), 69-79.

Inman, D.L., Elwany, M.H.S., Jenkins, S.A., 1993. Shorerise and Bar-Berm Profiles on Ocean Beaches. Journal of Geophysical Research, 98 (C10), 18181-18199.

Lahoz, M.G., Albiach, J.C.C., 2005. Wave forecasting at the Spanish coasts. Journal of Atmospheric \& Ocean Science, 10 (4), 389-405. 
Lee, G.H., Nicholls, R.J., Birkemeier, W.A., 1998. Storm-driven variability of the beachnearshore profile at Duck, North Carolina, USA, 1981-1991. Marine Geology, 148 (34), 163-177.

Long, J.W., Özkan-Haller, H.T., 2005. Offshore controls on nearshore rip currents. Journal of Geophysical Research, 110 (C12), C12007.

Loureiro, C., Ferreira, Ó., Cooper, J.A.G., 2011. Morphologic change and morphodynamics at high-energy embayed beaches in southwestern Portugal. Proceedings of Coastal Sediments 2011. World Scientific Publishing, Singapore. Vol 2, 1375-1389.

MacMahan, J.H., Thornton, E.B., Stanton, T.P., Reniers, A.J.H.M., 2005. RIPEX: Observations of a rip current system. Marine Geology, 218 (1-4), 113-134.

MacMahan, J.H., Thornton, E.B., Reniers, A.J.H.M., 2006. Rip current review. Coastal Engineering, 53 (2-3), 191-208.

MacMahan, J.H., Thornton, E.B., Reniers, A.J.H.M., Stanton, T.P., Symonds, G., 2008. Lowenergy rip currents associated with small bathymetric variations. Marine Geology, 255 (3-4), 156-164.

MacMahan, J.H., Brown, J., Brown, J., Thornton, E., Reniers, A., Stanton, T., Henriquez, M., Gallagher, E., Morrison, J., Austin, M.J., Scott, T.M., Sénéchal, N., 2010. Mean Lagrangian flow behaviout on an open coast rip-channeled beach: a new perspective. Marine Geology, 268 (1-4), 1-15.

McKenzie, P., 1958. Rip-current systems. Journal of Geology, 66 (2), 103-113.

Orzech, M.D., Thornton, E.B., MacMahan, J.H., O’Reilly, W.C., Stanton, T.P., 2010. Alongshore rip channel miigration and sediment transport. Marine Geology, 271 (3-4), 278-291.

Pattiaratchi, C., Olsson, D., Hetzel, Y., Lowe, R., 2009. Wave-driven circulation patterns in the lee of groynes. Continental Shelf Research, 29 (16), 1961-1974. 
875 Pita, C., Santos, J.A., 1989. Análise dos temporais da costa oeste de Portugal Continental, Report NATO PO-WAVES 1/89-A. IH/LNEC, Lisboa, Portugal.

Ranasinghe, R., Symonds, G., Black, K., Holman, R., 2004. Morphodynamics of intermediate beaches: a video imaging and numerical modelling study. Coastal Engineering, 51 (7), 629-655.

Short, A.D., 1979. Three dimensional beach-stage model. Journal of Geology, 87 (5), $553-$ 571.

Short, A.D., 1985. Rip-current type, spacing and persistence, Narrabeen Beach, Australia. Marine Geology, 65 (1-2), 47-71.

Short, A.D. (Ed.), 1999. Handbook of Beach and Shoreface Morphodynamics, John Wiley \& Sons, Chichester. 379 pp.

Short, A.D., 2007. Australian rip systems: friend or foe?. Journal of Coastal Research, SI 50, $7-11$.

Short, A.D., 2010. Role of geological inheritance in Australian beach morphodynamics. Coastal Engineering, 57 (2), 92-97.

Short, A.D., Hesp, P.A., 1982. Wave, beach and dune interaction in Southeastern Australia. Marine Geology, 48 (3-4), 259-284.

Short, A.D., Masselink, G. 1999. Embayed and structurally controlled beaches. In: Short, A.D. (Ed.), Handbook of Beach and Shoreface Morphodynamics, John Wiley \& Sons, Chichester, pp. 230-249.

Silva, R., Baquerizo, A., Losada, M.A., Mendonza, E., 2010. Hydrodynamics of a headlandbay beach - nearshore current circulation. Coastal Engineering, 57 (2), 160-175.

Smith, A.M., Mather, A.A., Bundy, S.C., Cooper, J.A.G., Guastella, L.A., Ramsay, P.J., Theron, A., 2010. Contrasting styles of swell-driven coastal erosion: examples from KwaZulu-Natal, South Africa. Geological Magazine, 147 (6), 940-953. 
900

901

902

903

904

905

906

907

908

909

910

911

912

913

914

915

916

917

918

919

920

921

922

923

924

Thom, B.G., 1974. Coastal erosion in Eastern Australia. Search, 5 (5), 198-209.

Thom, B.G., Hall, W., 1991. Behaviour of beach profiles during accretion and erosion dominated periods. Earth Surface Processes and Landforms, 16 (2), 113-127.

Turner, I.L., Whyte, D., Ruessink, B.G., Ranasinghe, R., 2007. Observations of rip spacing, persistence and mobility at a long, straight coastline. Marine Geology, 236 (3-4), 209221.

Wood, D.J., Muttray, M., Oumeraci, H., 2001. The SWAN model used to study wave evolution in a flume. Ocean Engineering, 28 (7), 805-823.

Wright, L.D., 1981. Beach cut in relation to surf zone morphodynamics. Proceedings of the 17th International Conference on Coastal Engineering. ASCE, Sydney, Australia, pp. 978-996.

Wright, L.D., Short, A.D., 1983. Morphodynamics of beaches and surf zones in Australia. In: Komar, P.D. (Ed.), CRC Handbook of Coastal Processes and Erosion. CRC Press, Boca Raton, Florida, pp. 35-64.

Wright, L.D., Short, A.D., 1984. Morphodynamic variability of surf zones and beaches - a synthesis. Marine Geology, 56 (1-4), 93-118.

Wright, L.D., Thom, B.G., Chappell, J., 1979. Morphodynamic variability of high-energy beaches. Proceedings of the 16th International Conference on Coastal Engineering. ASCE, Hamburg, Germany, pp. 1180-1194. 
$927 \quad$ Table 1

928 Mean offshore wave conditions used in model runs and corresponding alongshore averaged 929 breaking wave heights $\left(H_{b \bar{y}}\right)$ and standard deviation $\left(H_{b \sigma}\right)$ for Arrifana, Mt. Clérigo and 930 Amoreira embayments. Grey shading highlights modal conditions.

931

932

\section{Table 2}

933 Characteristics of observed storms from different directions used for model runs. Values of 934 $H_{s o}, T_{p}$ and $\theta$ are time averages for the duration of each event.

935

936

\section{Table 3}

937 Geometric and morphodynamic characteristics of the embayments.

938

939

940

941

942

943

944

945

946

947

948

949

950

951

952

953

954

955

956 


\section{LIST OF FIGURES}

Fig. 1. Geographical location of the study sites. Aerial view of Amoreira (A), Monte Clérigo (B) and Arrifana (C) embayments with indication of beach profiles location (black lines) and positions for image acquisition (stars). Bathymetry is given in metres below MSL. The wave rose was computed from Sines wave buoy data (black star in inset of location image), from September 2007 to September 2009. Colour web/ B\&W printing

Fig. 2. Synthesis of morphological features and graphical signatures used for classification of beach profiles and rip systems interaction. Flow arrows in the boundary diagram are not scaled to velocity. Colour web/ B\&W printing

Fig. 3. Location of Sines directional wave buoy (asterisk) and WANA grid points (crossed circles). Study sites are indicated by black dots and bathymetry is given in metres below MSL. Colour web/ B\&W printing

Fig. 4. Nested grids used in SWAN runs. The small grids for each beach are nested into a medium resolution grid encompassing the entire nearshore area of the study sites, which is then nested into a larger grid of the south-west coast of Portugal (entire area of this figure), for which water depths below MSL are provided. Colour web/ B\&W printing

Fig. 5. Time series of offshore significant wave height $\left(H_{s o}\right)$, peak period $\left(T_{p}\right)$ and peak wave direction $(\theta)$ from September 2007 to September 2009. Circles in the top panel indicate timing of beach surveys. Shading highlights high-energy events (light grey) and extreme events (dark grey) during the monitoring period. Colour web/ B\&W printing

Fig. 6. Time series of offshore significant wave height $\left(H_{s o}\right)$ (top panel) and cumulative volume changes for Arrifana beach profiles (black solid line in lower panels). Circles represent profile and rip interaction, with black, grey and hollow circles indicating the influence of rip neck, feeder channel and no rip influence, respectively. Shaded bars highlight high energy events. B\&W web and printing 
Fig. 7. Time series of offshore significant wave height $\left(H_{s o}\right)$ (top panel) and cumulative volume changes for Mt. Clérigo beach profiles (black solid line in lower panels). Refer to Fig. 6 caption for description of symbols. B\&W web and printing

Fig. 8. Time series of offshore significant wave height $\left(H_{s o}\right)$ (top panel) and cumulative volume changes for Amoreira beach profiles (black solid line in lower panels). Refer to Fig. 6 caption for description of symbols. B\&W web and printing

Fig. 9. Alongshore variation in breaking wave height $\left(H_{b}\right)$ for each embayment. Wave conditions were modelled for the storms identified in Table 2 (left panel) and for synthetic storms (right panel). Synthetic storms have constant offshore wave height (5 m) and peak period (15 s), but variable offshore wave directions of $315^{\circ}(\mathrm{NW}), 270^{\circ}(\mathrm{W})$ and $225^{\circ}(\mathrm{SW})$. Profile location is represented by grey vertical lines. $\mathbf{B} \& \mathbf{W}$ web and printing

Fig. 10. Modelled significant wave height $\left(H_{s}\right)$ for the average conditions recorded during the January-February 2009 storm group (offshore boundary conditions: $H_{s o}-4.5 \mathrm{~m} ; T_{p}-14.5 \mathrm{~s} ; \theta$ - $300^{\circ}$ ), at Arrifana (top panel), Mt. Clérigo (centre panel) and Amoreira (bottom panel). Depth contours (dotted lines) are in metres below MSL, and black lines indicate profile location. Colour web and printing

Fig. 11. Embayment scaling parameter $\left(\delta^{\prime}\right)$ for different alongshore averaged breaking wave heights $\left(H_{b \bar{y}}\right)$ in each embayment (refer to Table 1). Shading highlights modal conditions at each embayment. B\&W web and printing

Fig. 12. Panoramic mosaics of megarip circulation during storm and post-storm wave conditions for Arrifana. The upper panel presents the embayment under storm conditions, recorded on 05/02/2009 under 5.5 m WNW offshore waves. Arrows provide flow-behaviour indications of the megarips, and dashed lines indicate rip head plumes. The intense wave breaking across the entire surfzone is reduced within the rip-neck channel due to wave-current interaction. Post-storm conditions, recorded on 09/02/2009, are shown in the lower panel. Dark patches and the absence of wave breaking on both beach extremities indicate the position of the feeder channels and deep rip-neck channels. Colour web and printing 
1022 Fig. 13. Schematic mapping of megarip circulations during storm (left panel) and post-storm 1023 conditions (right panel) for Arrifana embayment. Rip neck channels (limited by solid black 1024 lines) are indicated for both storm and post storm conditions; while feeder channels (limited 1025 by dashed black line) are only clearly identifiable during post-storm conditions (refer to 1026 Figure 12 for snapshot view). Arrows indicate flow direction only and are not scaled to 1027 velocity, and bathymetry is in metres below MSL. B\&W web and printing

1029 Fig. 14. Schematic mapping of megarip circulations during storm (left panel) and post-storm conditions (right panel) for Mt. Clérigo embayment. Refer to Fig. 13 caption for description of symbols. B\&W web and printing

Fig. 15. Schematic mapping of megarip circulations during storm (left panel) and post-storm symbols. B\&W web and printing 
Table 1

Mean offshore wave conditions used in model runs and corresponding alongshore averaged breaking wave heights $\left(H_{b \bar{y}}\right)$ and standard deviation $\left(H_{b \sigma}\right)$ for Arrifana, Mt. Clérigo and Amoreira embayments. Grey shading highlights modal conditions.

\begin{tabular}{|c|c|c|c|c|c|c|c|c|c|}
\hline \multirow{2}{*}{$\begin{array}{c}\boldsymbol{H}_{\text {so }} \\
\text { Classes }\end{array}$} & \multicolumn{3}{|c|}{ Mean offshore conditions } & \multicolumn{2}{|c|}{ Arrifana } & \multicolumn{2}{|c|}{ Mt. Clérigo } & \multicolumn{2}{|c|}{ Amoreira } \\
\hline & $\begin{array}{l}H_{s o} \\
(\mathrm{~m})\end{array}$ & $\begin{array}{l}T_{p} \\
(\mathrm{~s})\end{array}$ & $\begin{array}{l}\theta \\
\left({ }^{\circ}\right)\end{array}$ & $\begin{array}{c}H_{b \bar{y}} \\
(\mathrm{~m})\end{array}$ & $\begin{array}{c}H_{b \sigma} \\
(\mathrm{m})\end{array}$ & $\begin{array}{r}H_{b \bar{y}} \\
(\mathrm{~m})\end{array}$ & $\begin{array}{c}H_{b \sigma} \sigma \\
(\mathrm{m})\end{array}$ & $\begin{array}{r}H_{b y} \\
(\mathrm{~m})\end{array}$ & $\begin{array}{c}H_{b} \\
(\mathrm{~m})\end{array}$ \\
\hline $0.5-1.0$ & 0.81 & 9.4 & 297 & 0.55 & 0.08 & 0.87 & 0.04 & 0.82 & 0.09 \\
\hline $1.0-1.5$ & 1.26 & 10.1 & 300 & 0.88 & 0.12 & 1.43 & 0.04 & 1.37 & 0.09 \\
\hline $1.5-2.0$ & 1.73 & 11.2 & 302 & 1.03 & 0.14 & 1.66 & 0.05 & 1.62 & 0.08 \\
\hline $2.0-2.5$ & 2.22 & 12.0 & 301 & 1.47 & 0.20 & 2.38 & 0.04 & 2.33 & 0.08 \\
\hline $2.5-3.0$ & 2.75 & 12.6 & 299 & 1.94 & 0.27 & 3.08 & 0.02 & 3.05 & 0.03 \\
\hline $3.0-3.5$ & 3.21 & 12.9 & 299 & 2.20 & 0.31 & 3.48 & 0.02 & 3.45 & 0.03 \\
\hline $3.5-4.0$ & 3.76 & 13.5 & 297 & 2.38 & 0.35 & 3.74 & 0.03 & 3.71 & 0.03 \\
\hline $4.0-4.5$ & 4.26 & 14.2 & 297 & 2.57 & 0.36 & 4.00 & 0.03 & 3.97 & 0.03 \\
\hline $4.5-5.0$ & 4.73 & 14.2 & 294 & 2.82 & 0.42 & 4.35 & 0.03 & 4.32 & 0.03 \\
\hline $5.0-5.5$ & 5.23 & 14.6 & 294 & 3.18 & 0.48 & 4.88 & 0.03 & 4.86 & 0.03 \\
\hline $5.5-6.0$ & 5.75 & 15.2 & 296 & 3.74 & 0.59 & 5.75 & 0.04 & 5.73 & 0.04 \\
\hline $6.0-6.5$ & 6.25 & 15.3 & 298 & 4.03 & 0.67 & 6.25 & 0.04 & 6.23 & 0.05 \\
\hline $6.5-7.0$ & 6.63 & 15.7 & 297 & 4.39 & 0.77 & 6.80 & 0.05 & 6.79 & 0.05 \\
\hline$>7.0$ & 7.82 & 17.1 & 298 & 4.62 & 0.85 & 7.23 & 0.05 & 7.22 & 0.06 \\
\hline
\end{tabular}


Table 2

Characteristics of observed storms from different directions used for model runs. Values of $H_{s o}, T_{p}$ and $\theta$ are time averages for the duration of each event.

\begin{tabular}{lccc}
\hline Storm & WNW & W & WSW \\
\hline Start date & $14 / 12 / 2008$ & $01 / 02 / 2009$ & $10 / 04 / 2008$ \\
Duration (hours) & 15 & 32 & 5 \\
$H_{s o}(\mathrm{~m})$ & 5.16 & 5.50 & 5.31 \\
$T_{p}(\mathrm{~s})$ & 13.8 & 13.6 & 11.9 \\
$\theta\left({ }^{\mathrm{o}}\right.$ from North $)$ & 309 & 275 & 241 \\
\hline
\end{tabular}


Table 3

Geometric and morphodynamic characteristics of the embayments.

\begin{tabular}{lccc}
\hline Parameters & Arrifana & Mt. Clérigo & Amoreira \\
\hline Embayment shoreline length $(\mathrm{m})$ & 2050 & 950 & 820 \\
Embayment width $(\mathrm{m})$ & 1340 & 780 & 570 \\
Beachface slope $\left(^{(}\right)$ & 2.2 & 2.0 & 1.3 \\
Modal $H_{b}(\mathrm{~m})$ & 1.03 & 1.66 & 1.62 \\
Modal $\delta^{\prime}$ & 30 & 7 & 7 \\
\hline
\end{tabular}




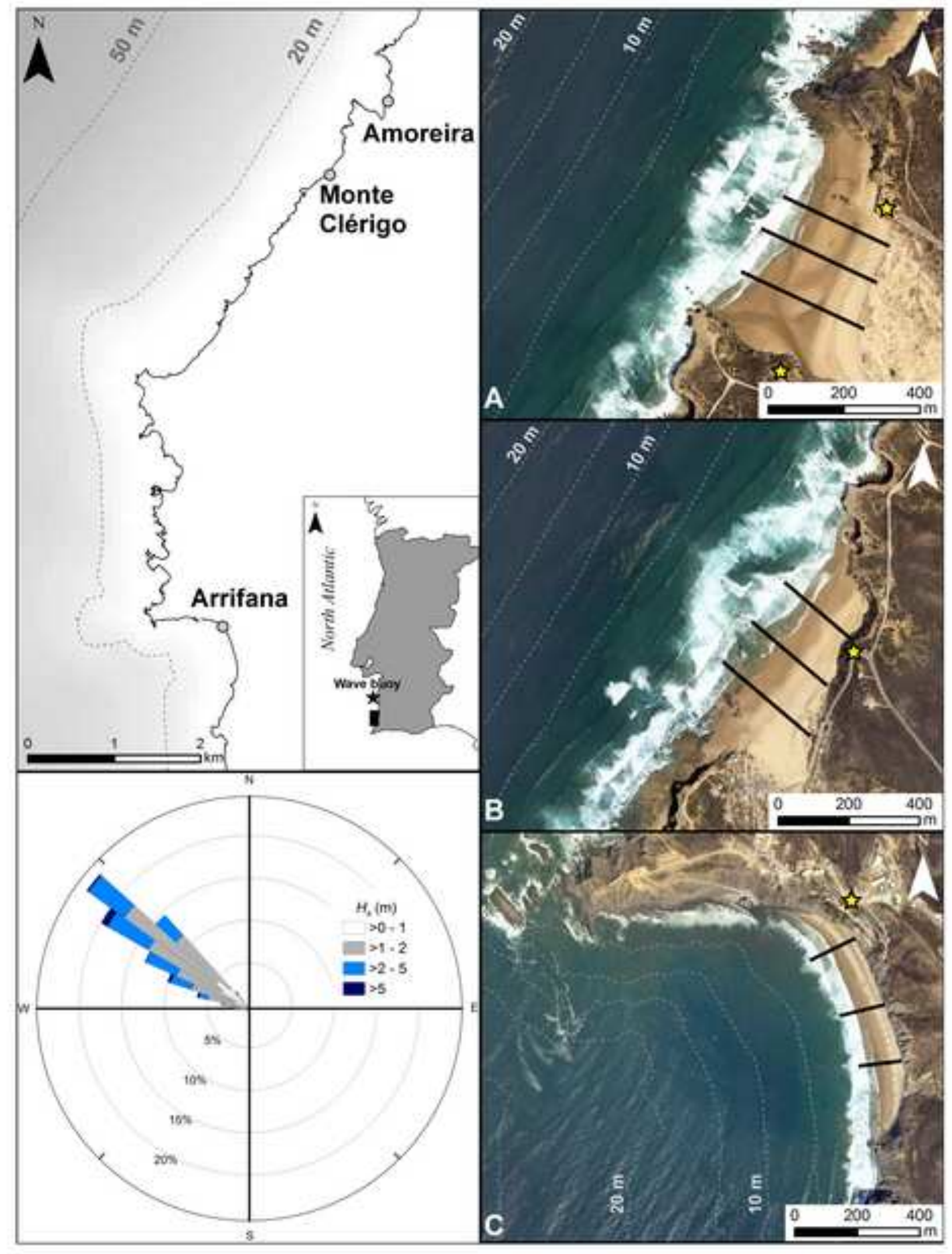

Figure 1 


\begin{tabular}{|c|c|c|c|}
\hline $\begin{array}{l}\begin{array}{r}\text { Profile and rip } \\
\text { interaction }\end{array} \\
\text { Parameters }\end{array}$ & $\begin{array}{l}\text { Profile intersected or } \\
\text { immediately adjacent } \\
\text { to rip-neck channel }\end{array}$ & $\begin{array}{l}\text { Profile intersected or } \\
\text { immediately adjacent } \\
\text { to feeder channel }\end{array}$ & $\begin{array}{l}\text { Profile without } \\
\text { influence of rip-neck or } \\
\text { feeder channels }\end{array}$ \\
\hline $\begin{array}{l}\text { Morphologic relief } \\
\text { - descrition }\end{array}$ & $\begin{array}{l}\text { - sharply inflected slope } \\
\text { - abrupt deepening } \\
\text { - cross-shore incision }\end{array}$ & $\begin{array}{l}\text { - intertidal trough } \\
\text { - bar seaward of trough } \\
\text { - alongshore incision }\end{array}$ & $\begin{array}{l}\text { - linear to concave slope } \\
\text { - smooth deepening } \\
\text { - no channel incision }\end{array}$ \\
\hline \multicolumn{4}{|l|}{$\begin{array}{l}\text { Morphologic relief } \\
\text { - cross-shore } \\
\text { intertidal profile } \\
\text { with (below) } \\
\text { and without (above) } \\
\text { terrace }\end{array}$} \\
\hline $\begin{array}{l}\text { Visual signature } \\
\text { - description }\end{array}$ & $\begin{array}{l}\text { - cross-shore orientation } \\
\text { - gaps in breaking line } \\
\text { - foam seaward of } \\
\text { breakers }\end{array}$ & $\begin{array}{l}\text { - alongshore orientation } \\
\text { - streaks of darker water } \\
\text { - breaking in the bar } \\
\text { seaward of trough }\end{array}$ & $\begin{array}{l}\text { - along and cross-shore } \\
\text { uniformity } \\
\text { - homogenous bores } \\
\text { - regular breaking line }\end{array}$ \\
\hline \multicolumn{4}{|l|}{$\begin{array}{l}\text { Visual signature } \\
\text { - photography }\end{array}$} \\
\hline \multirow[t]{2}{*}{ Boundary diagram } & & & \\
\hline & rip-neck feeder & beach $\rightarrow$ flow indication & Awave breaking $\square$ profile \\
\hline Flow direction & - offshore directed & - alongshore directed & - onshore directed \\
\hline
\end{tabular}




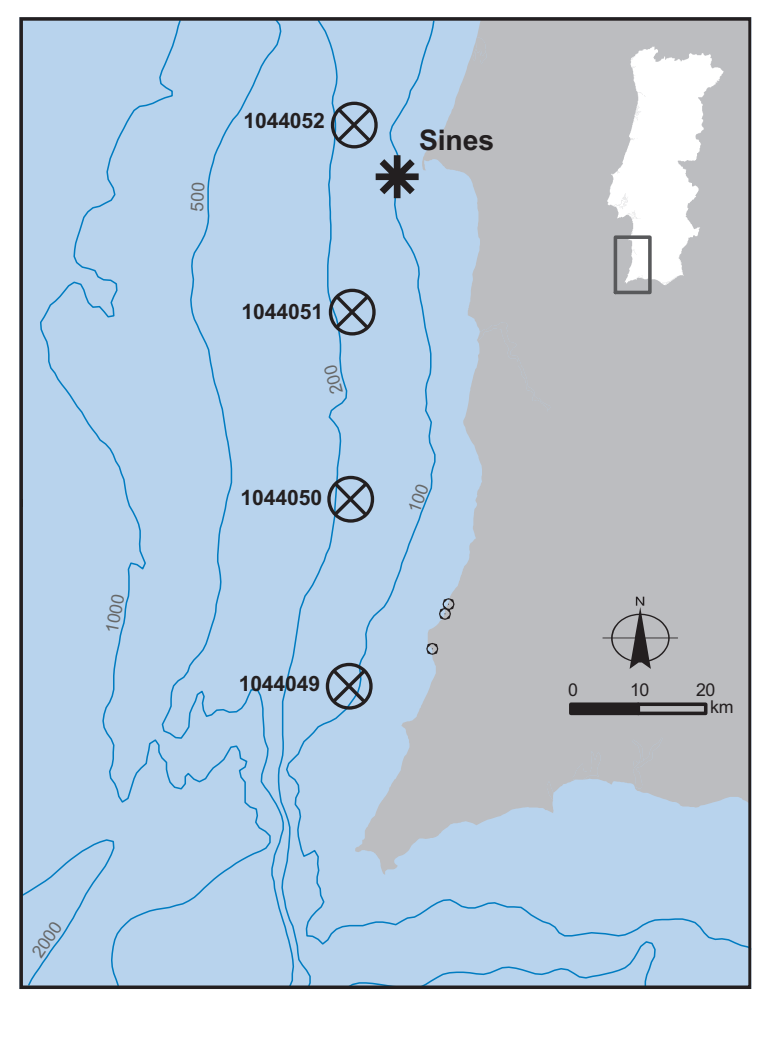

Figure 3

Figure 3

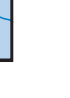

3

.
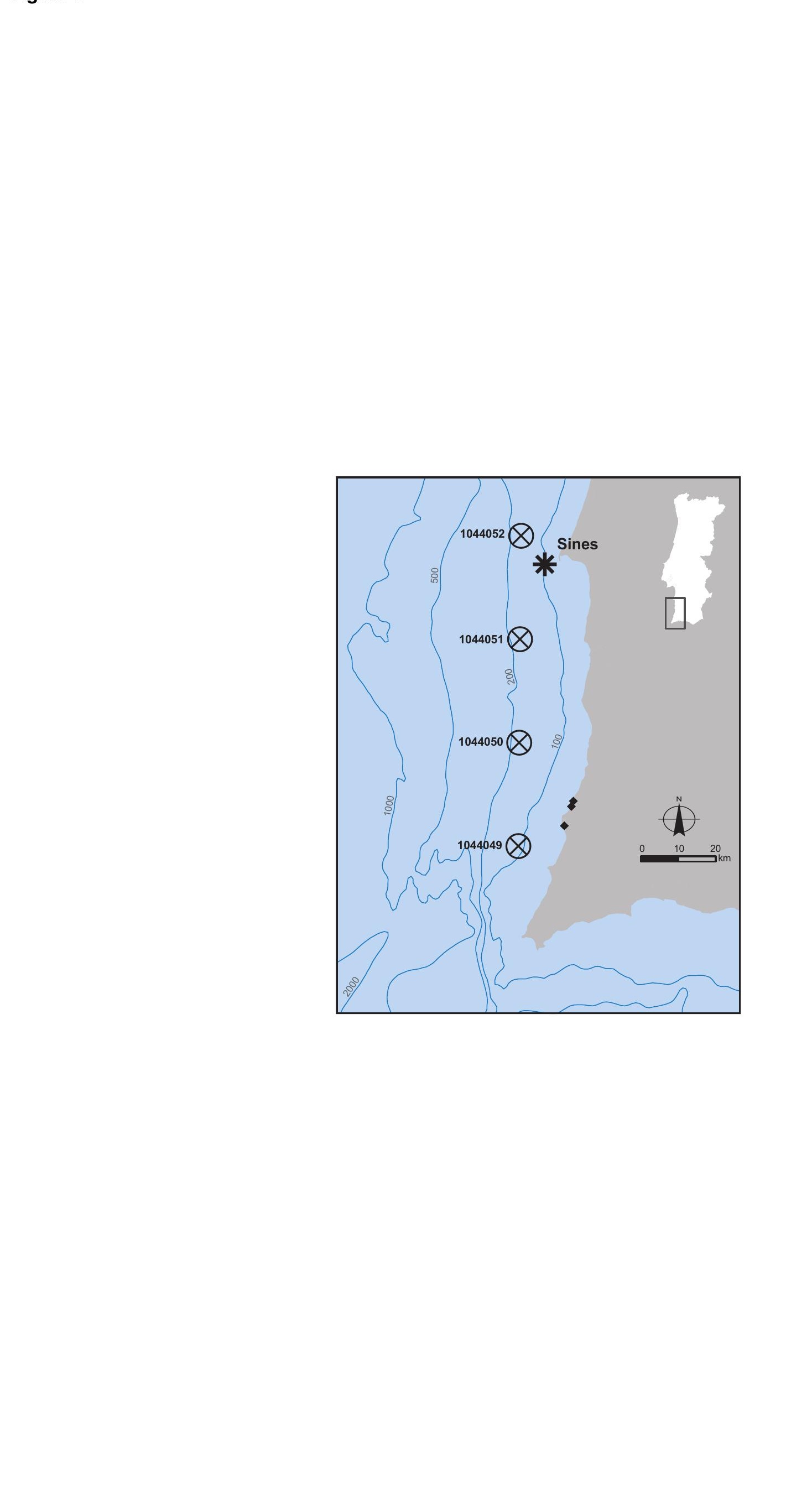

( 


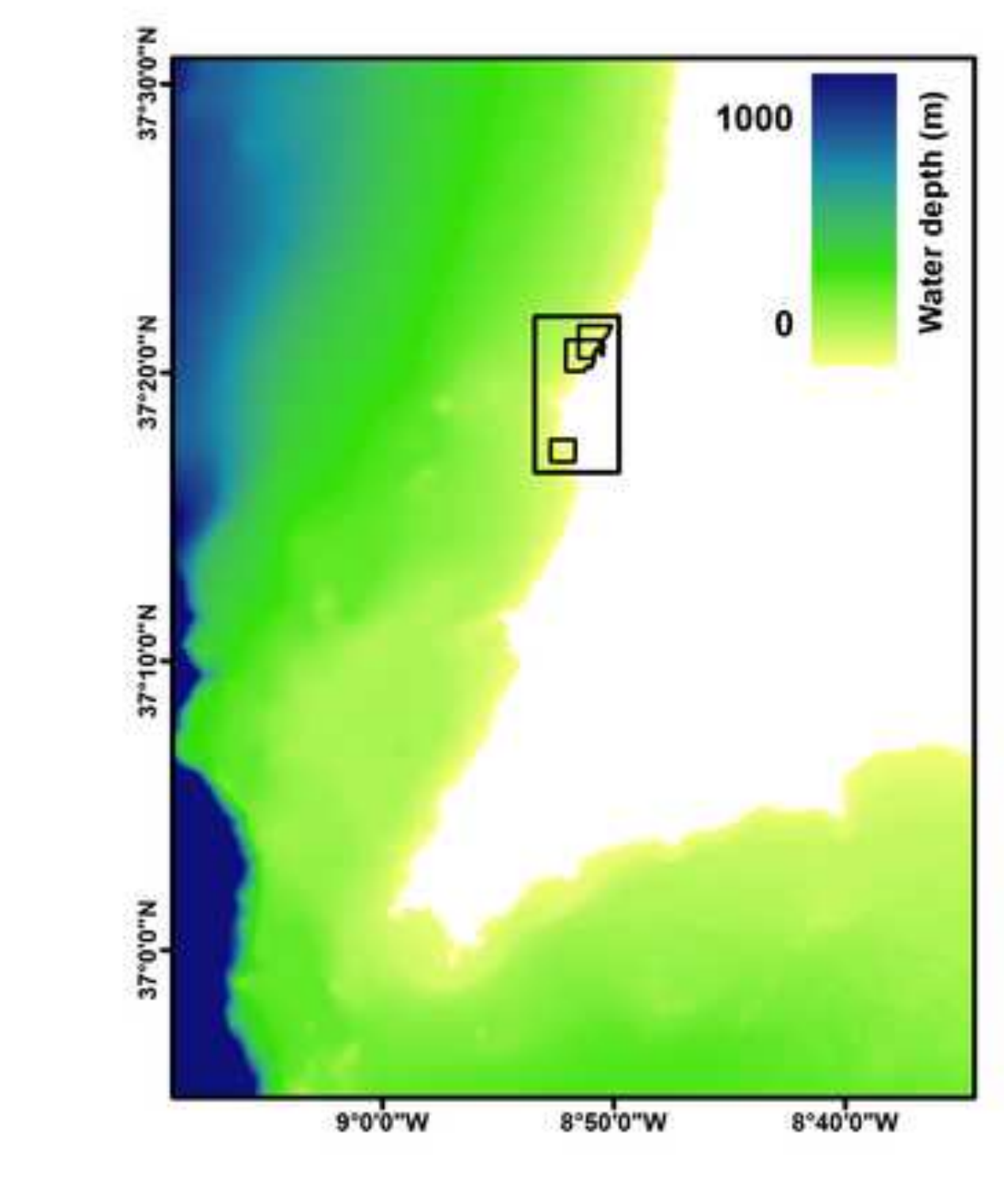

Figure 4

(2)

$$
\text { . }
$$

Figure 4

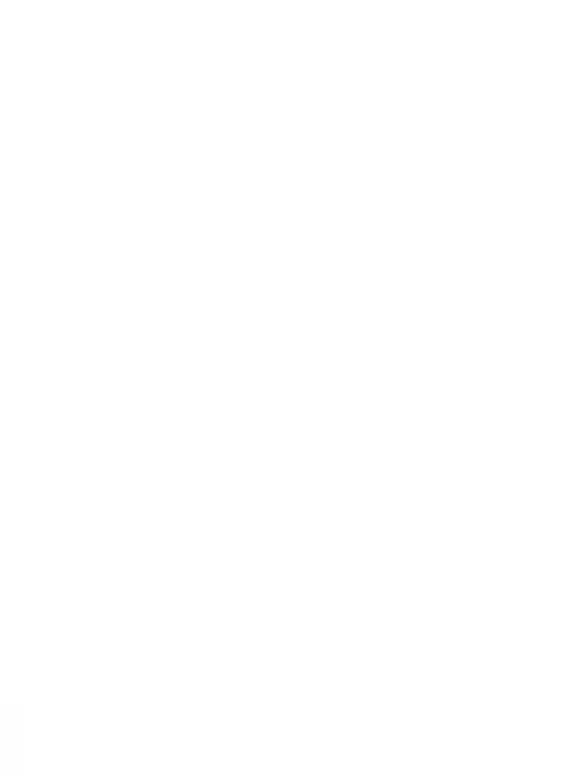

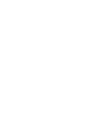


Figure 5
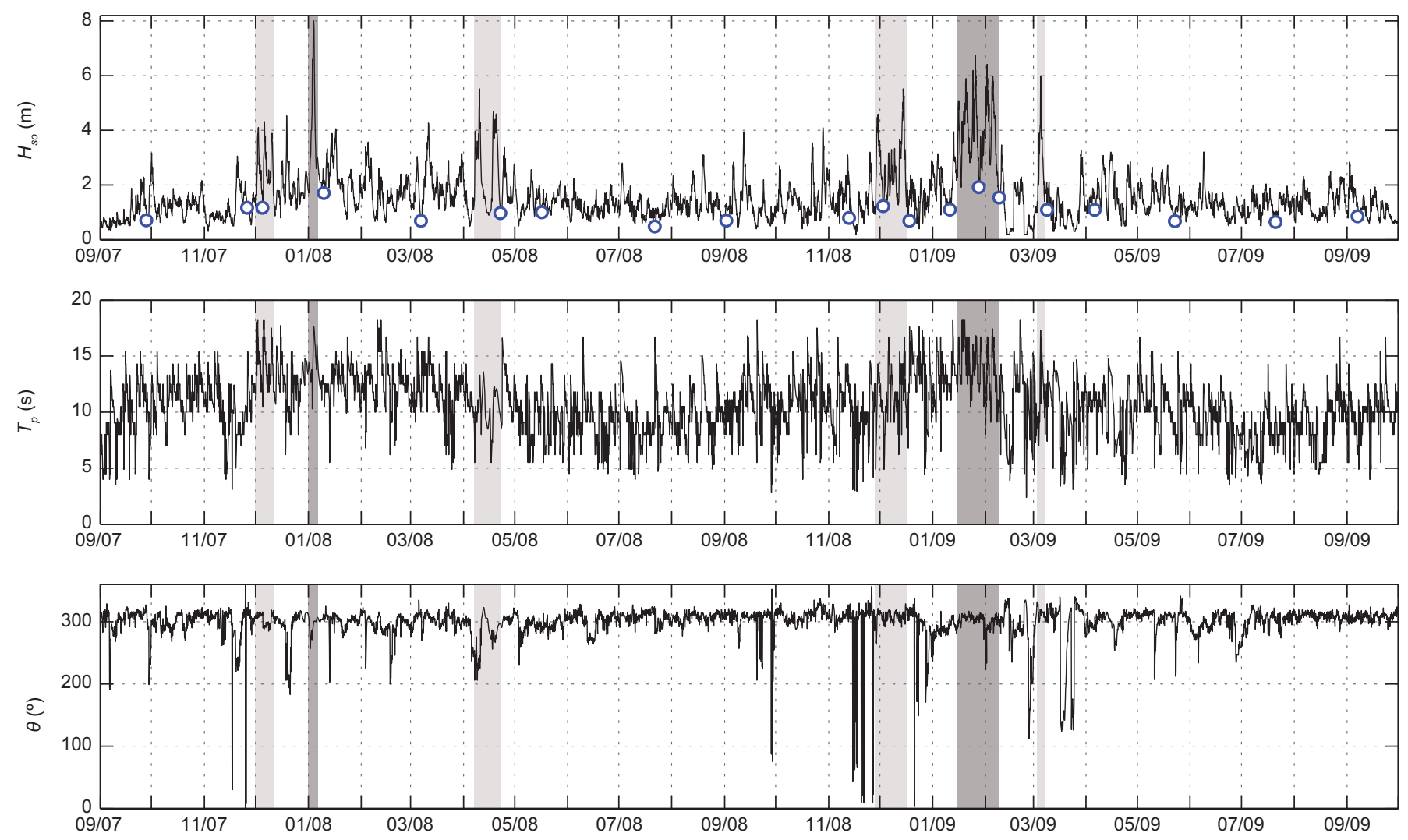

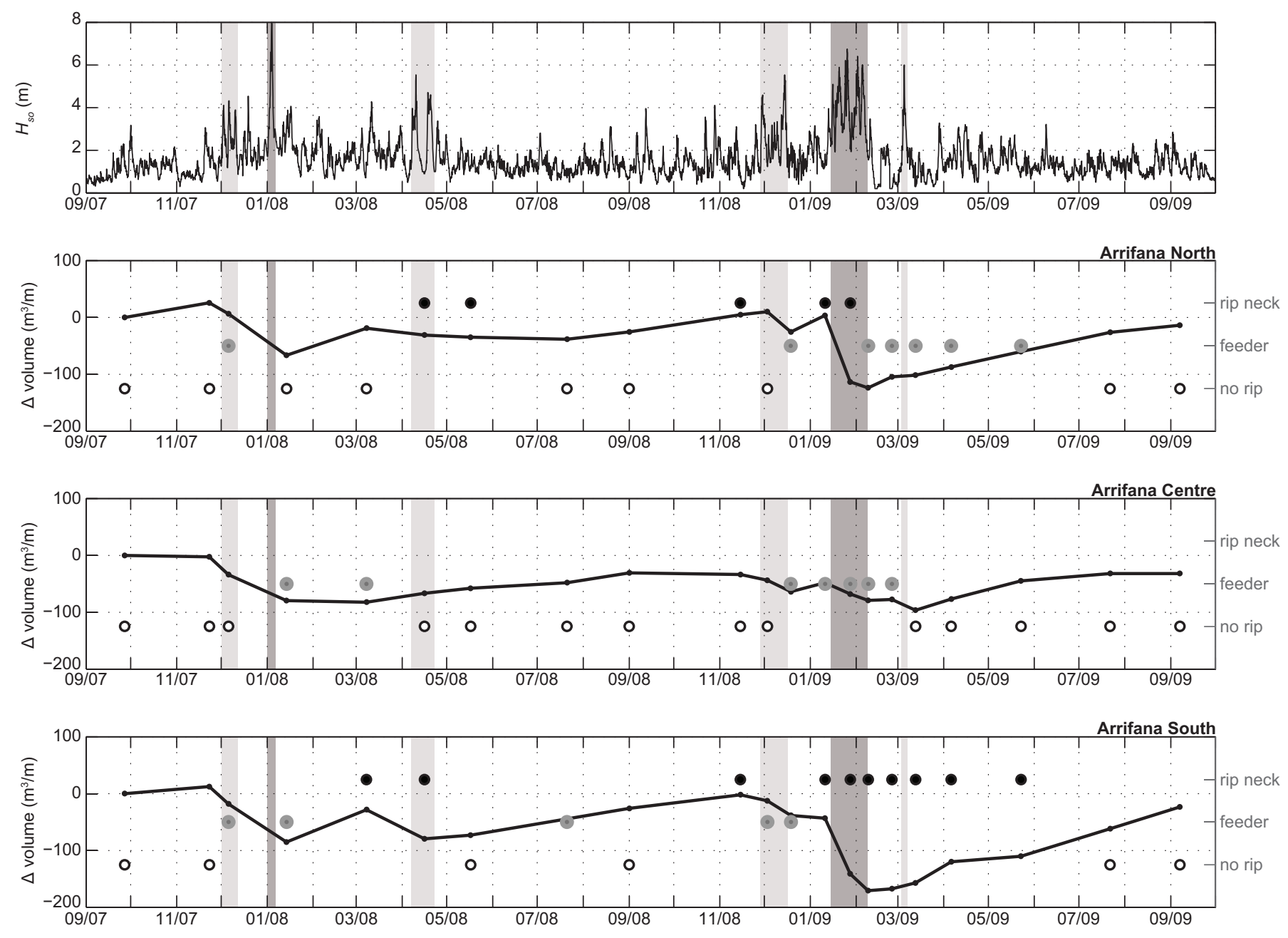
Figure 7
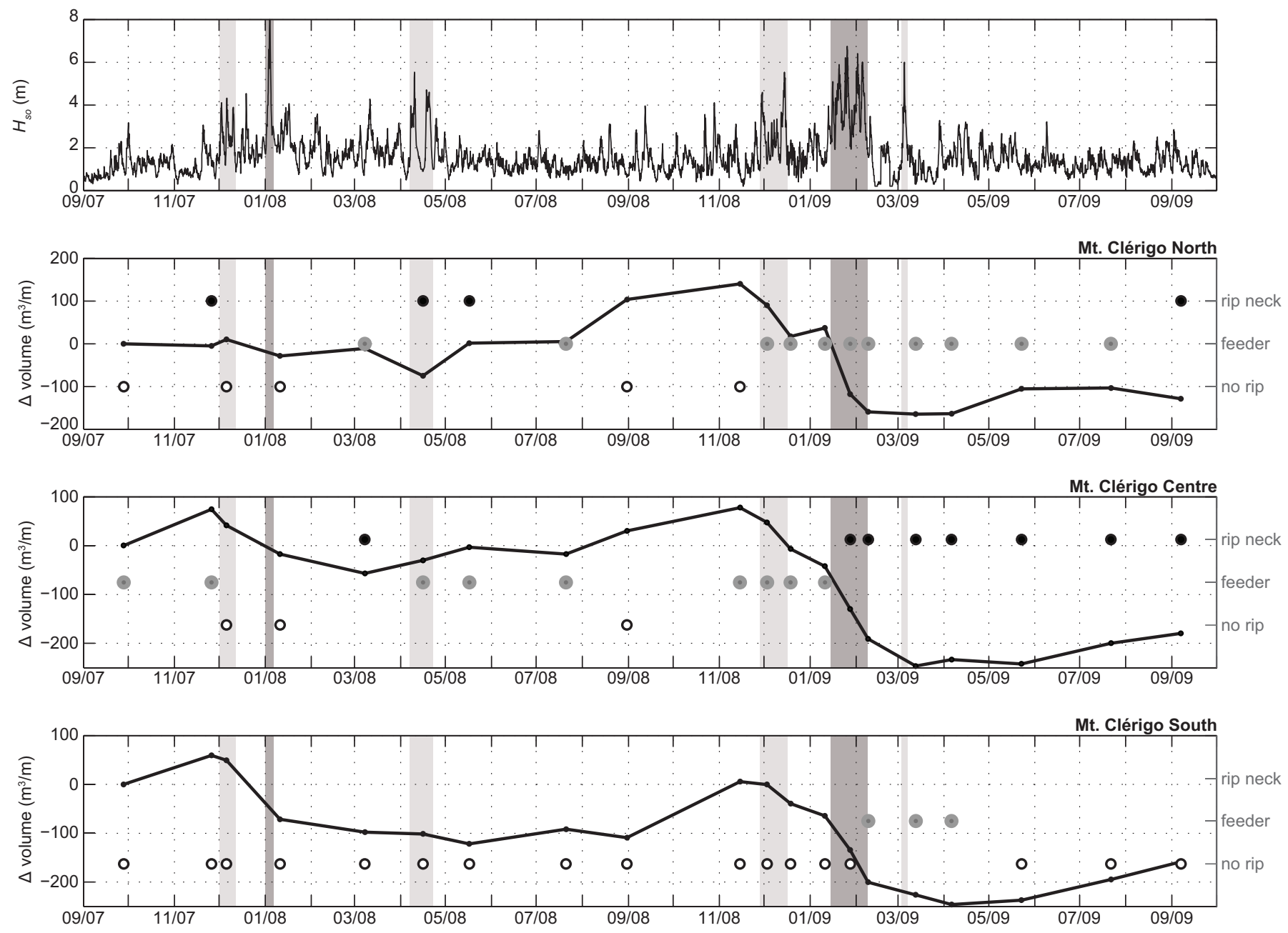
Figure 8
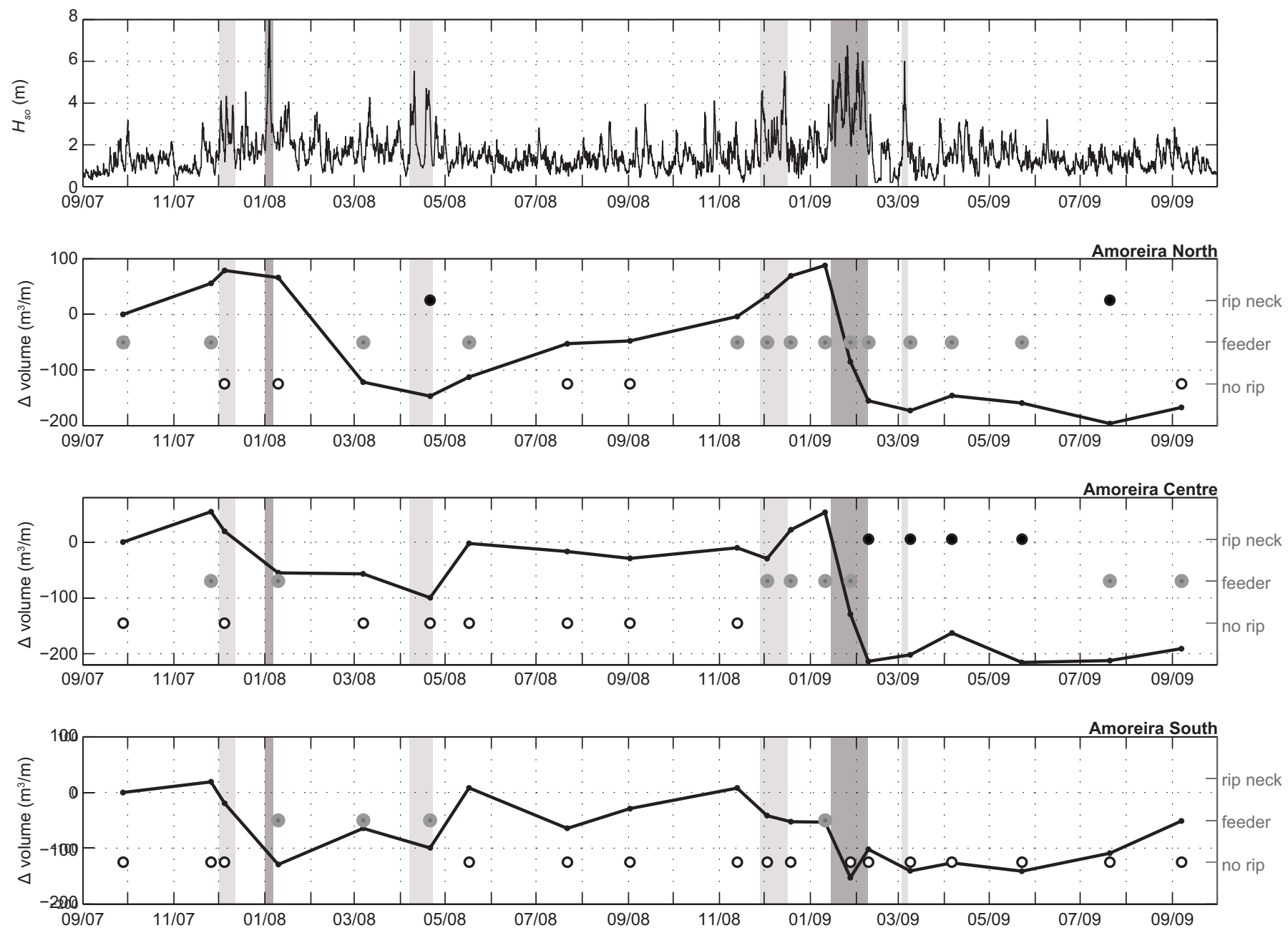
REAL STORMS

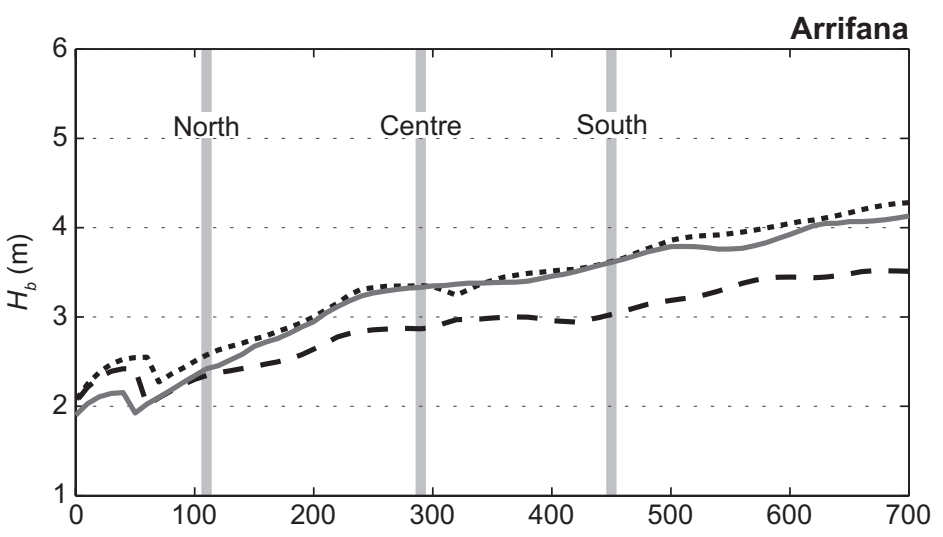

Mt. Clérigo
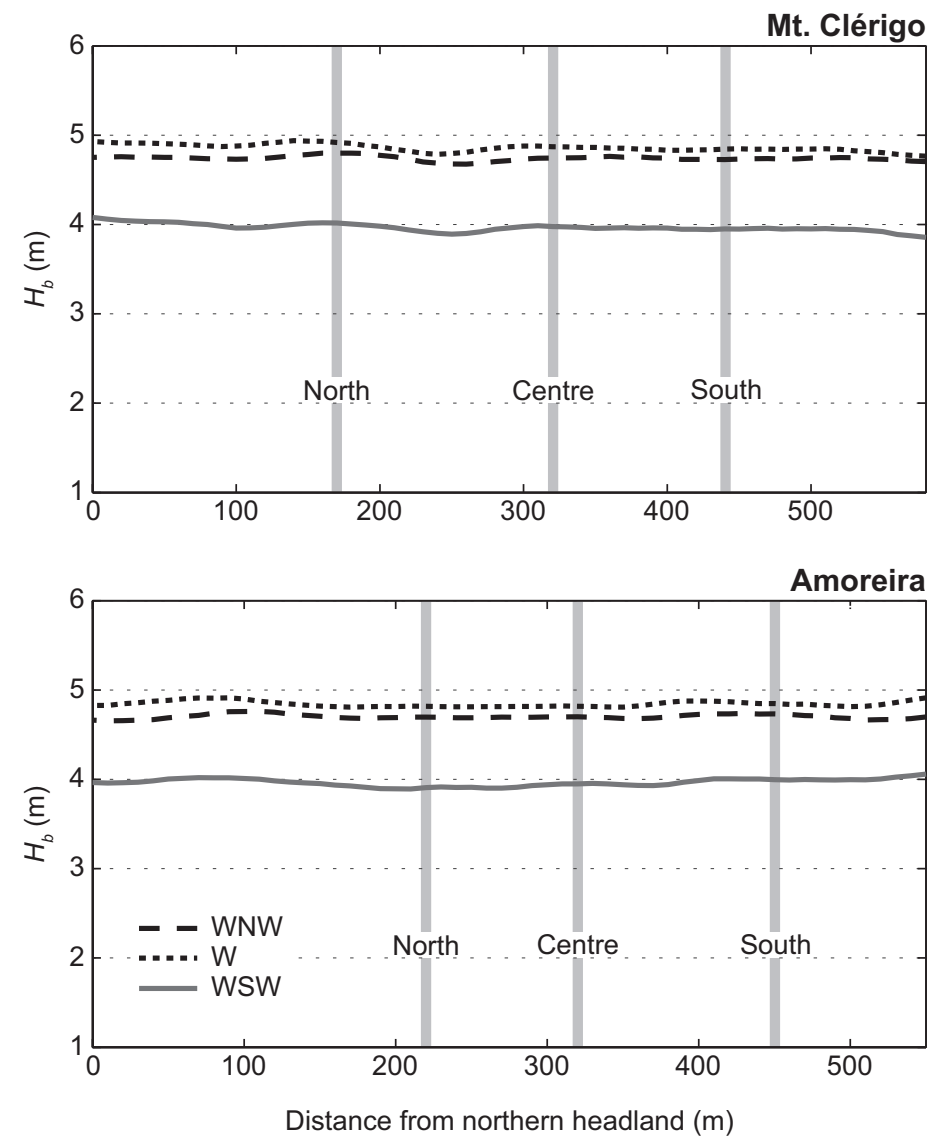

SYNTHETIC STORMS

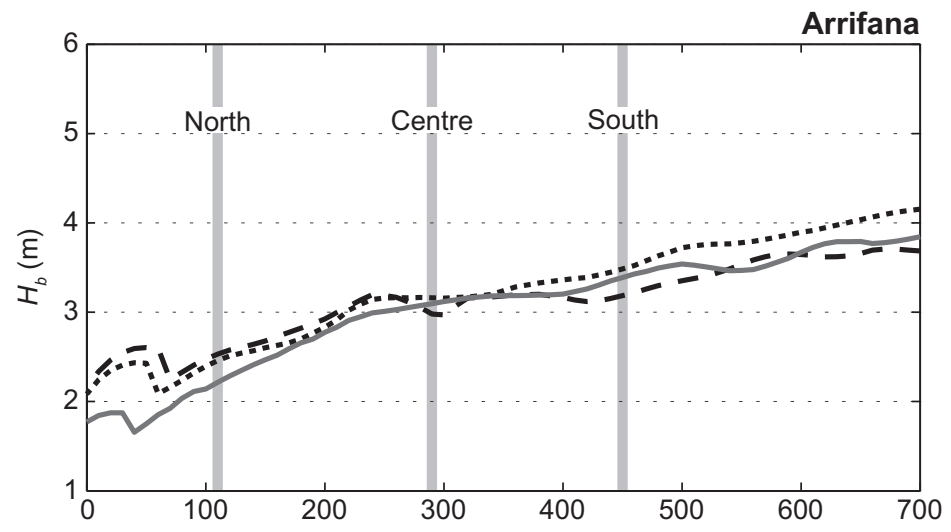

Mt. Clérigo
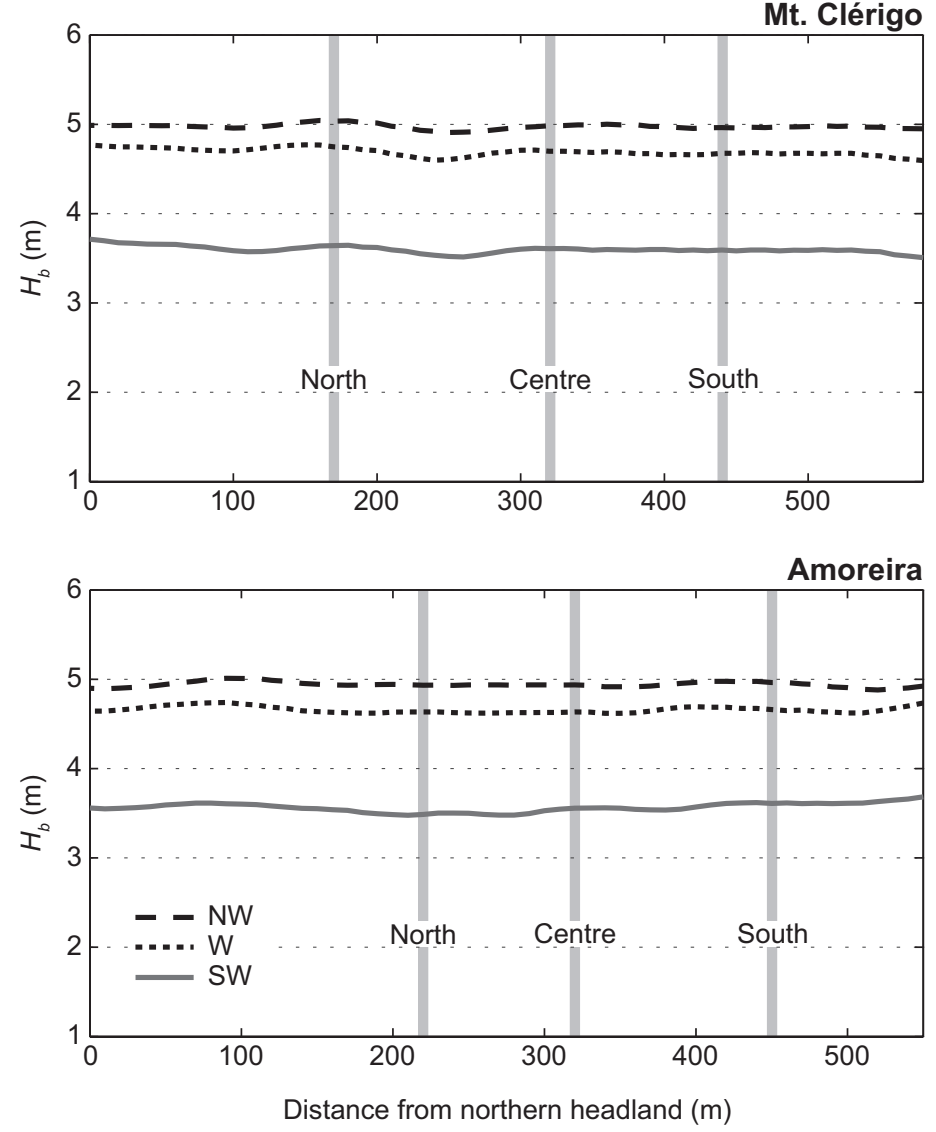
Figure 10
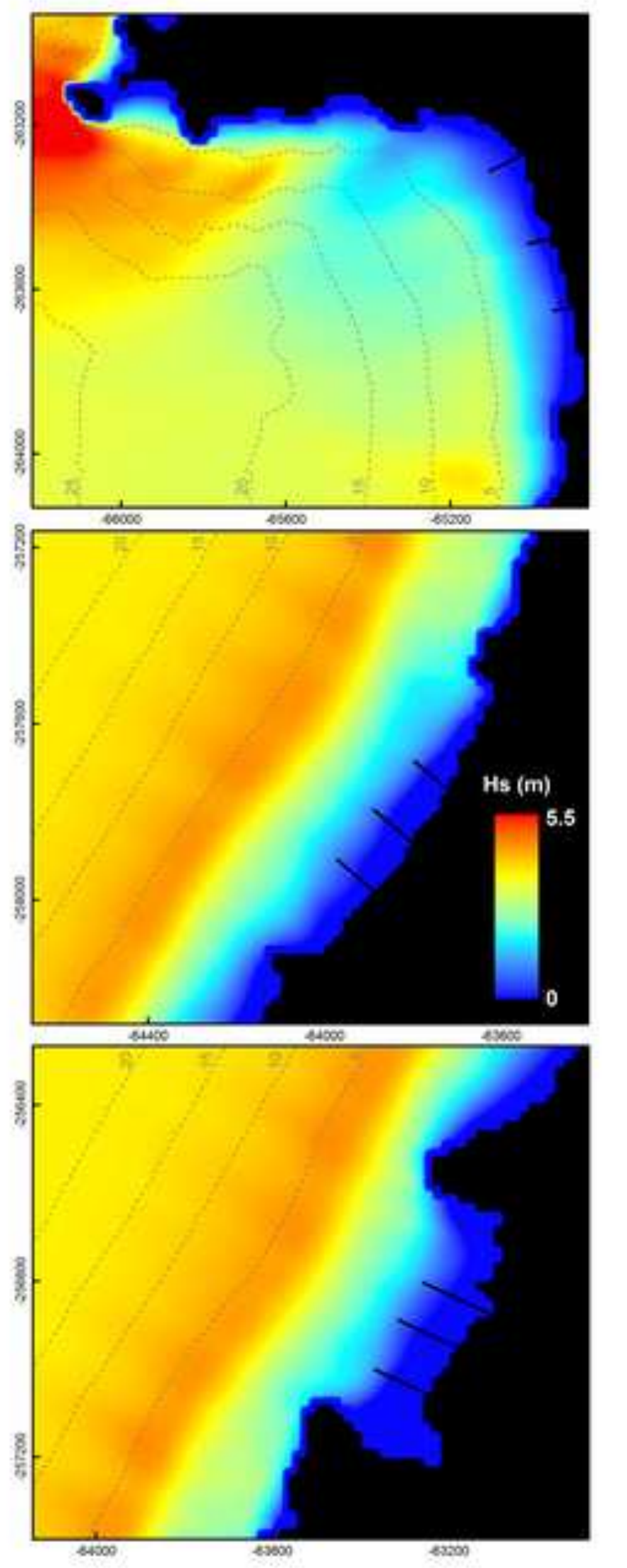

sxison

soson
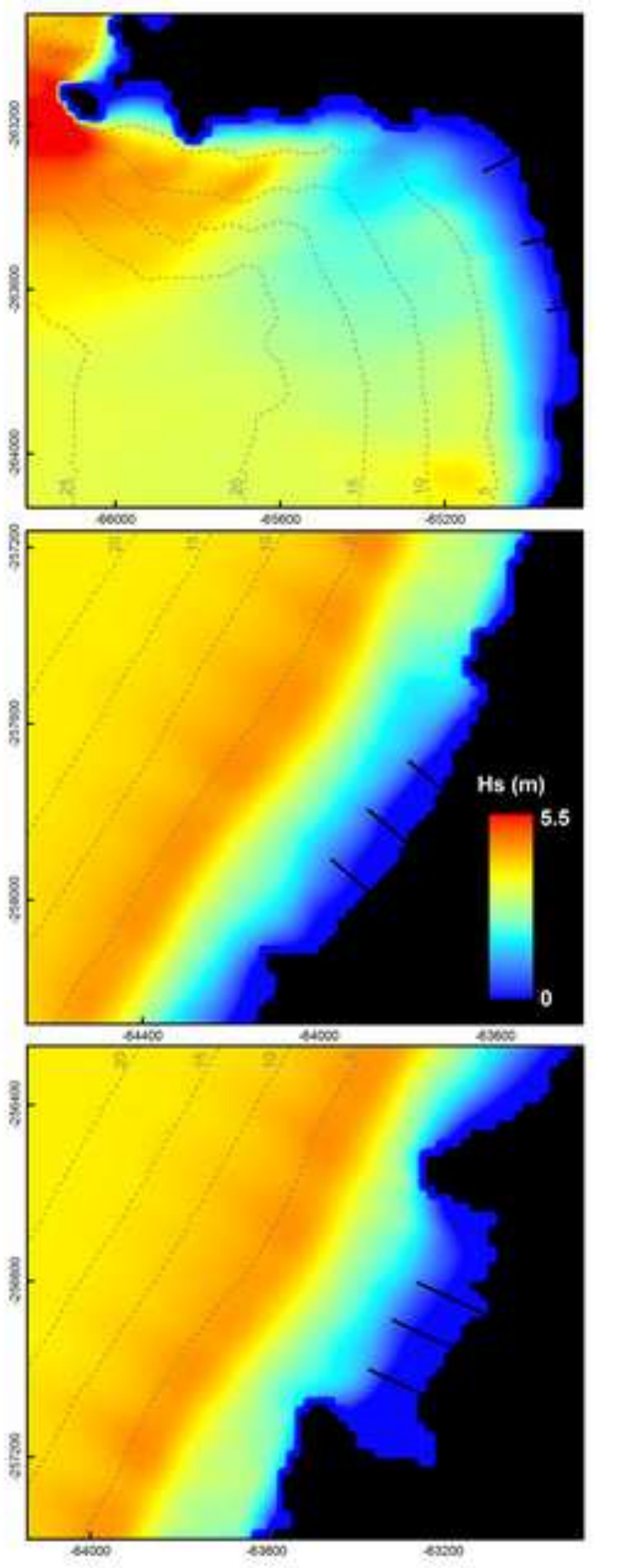


\section{Figure 11}

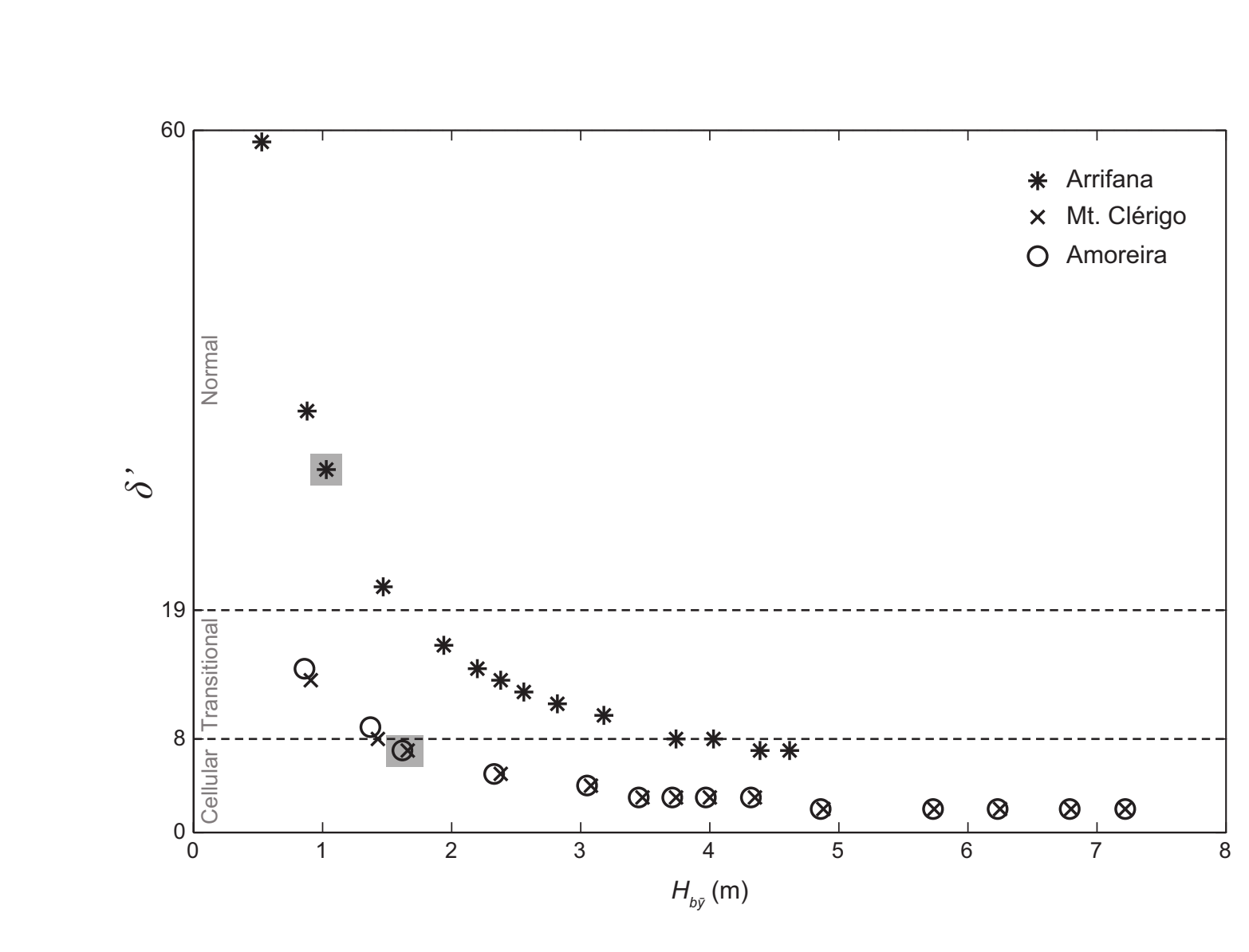

\section{Figure 11}

.

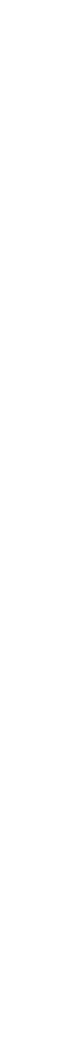

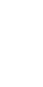

.

.
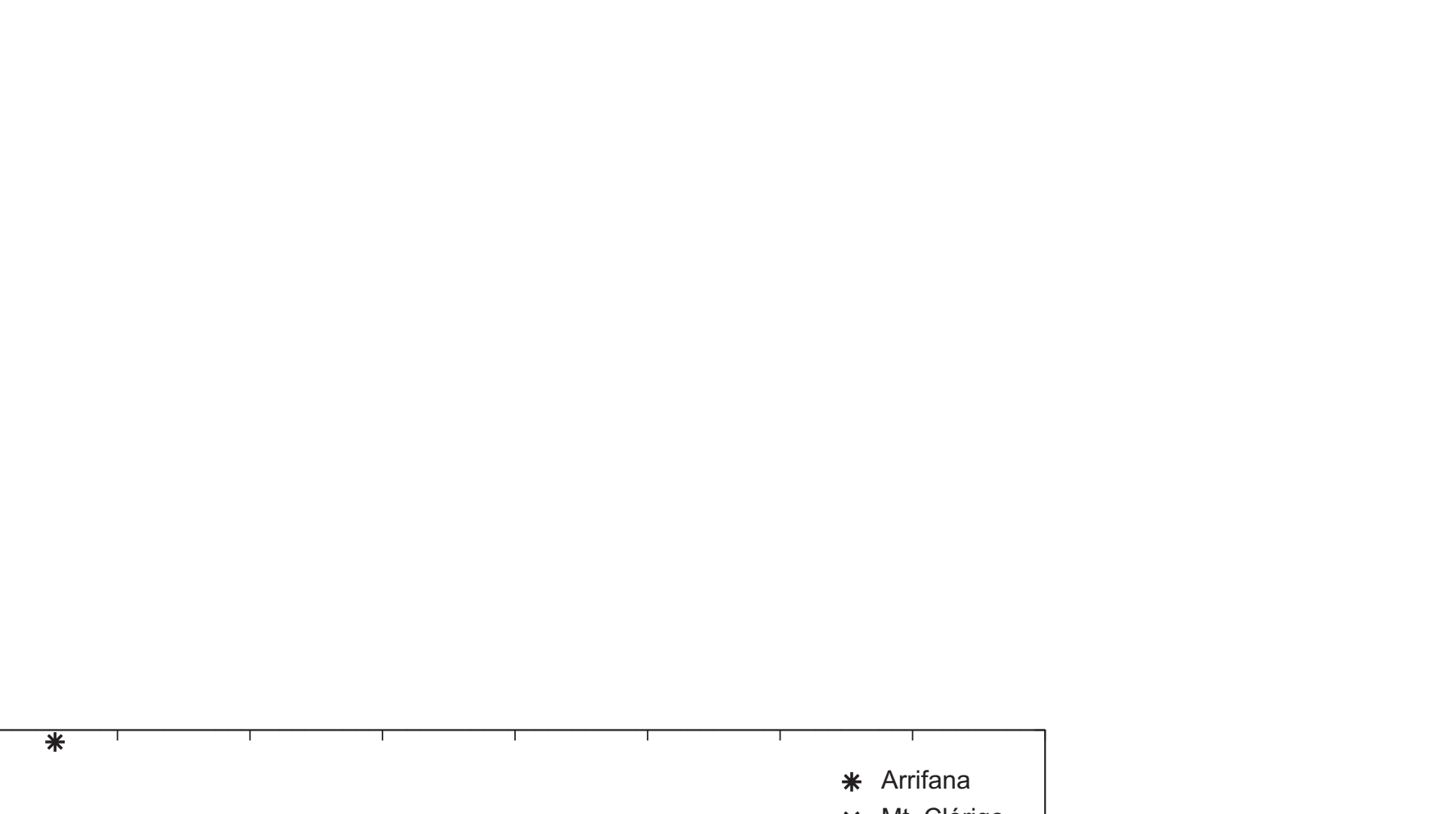


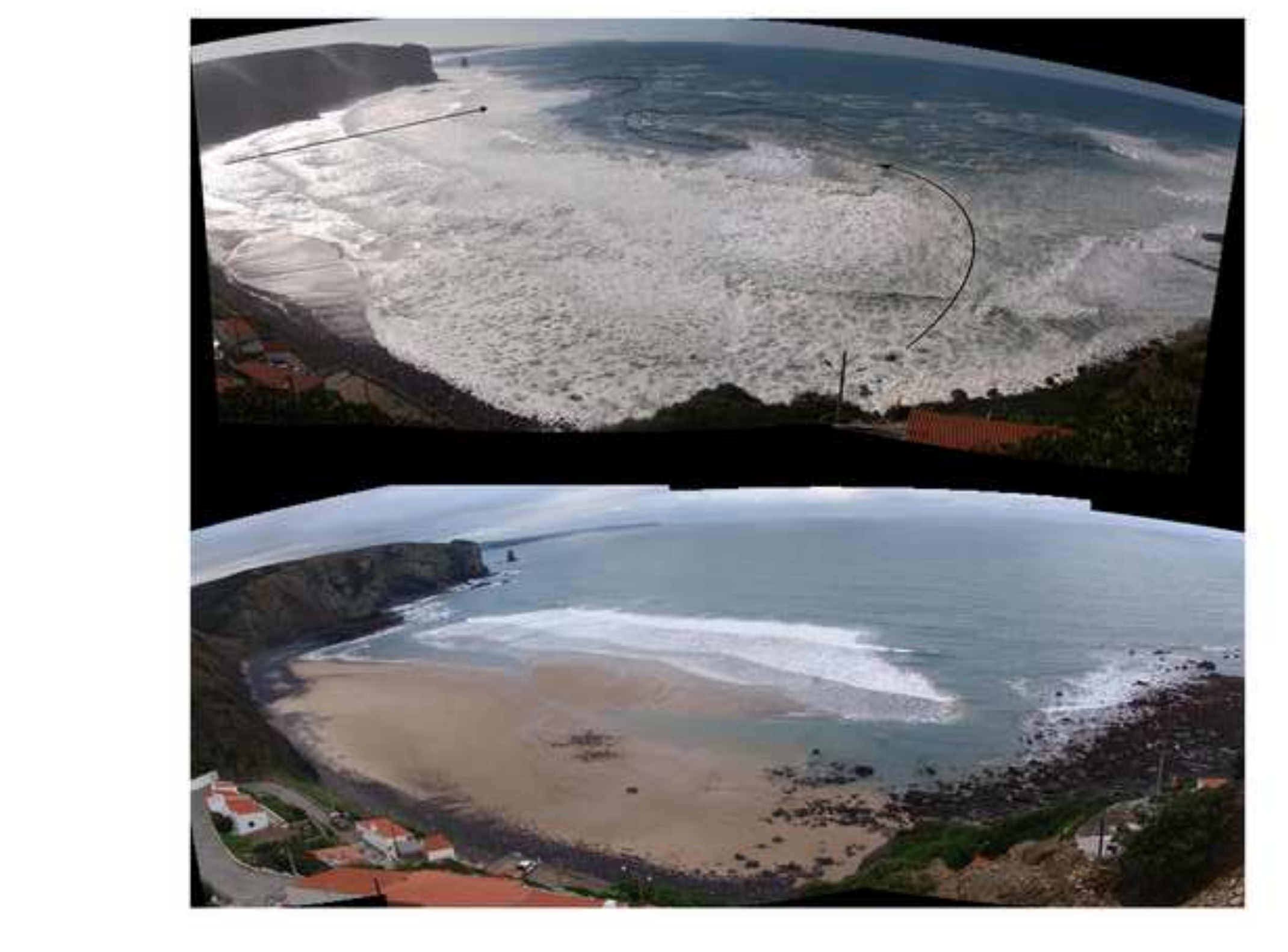

.
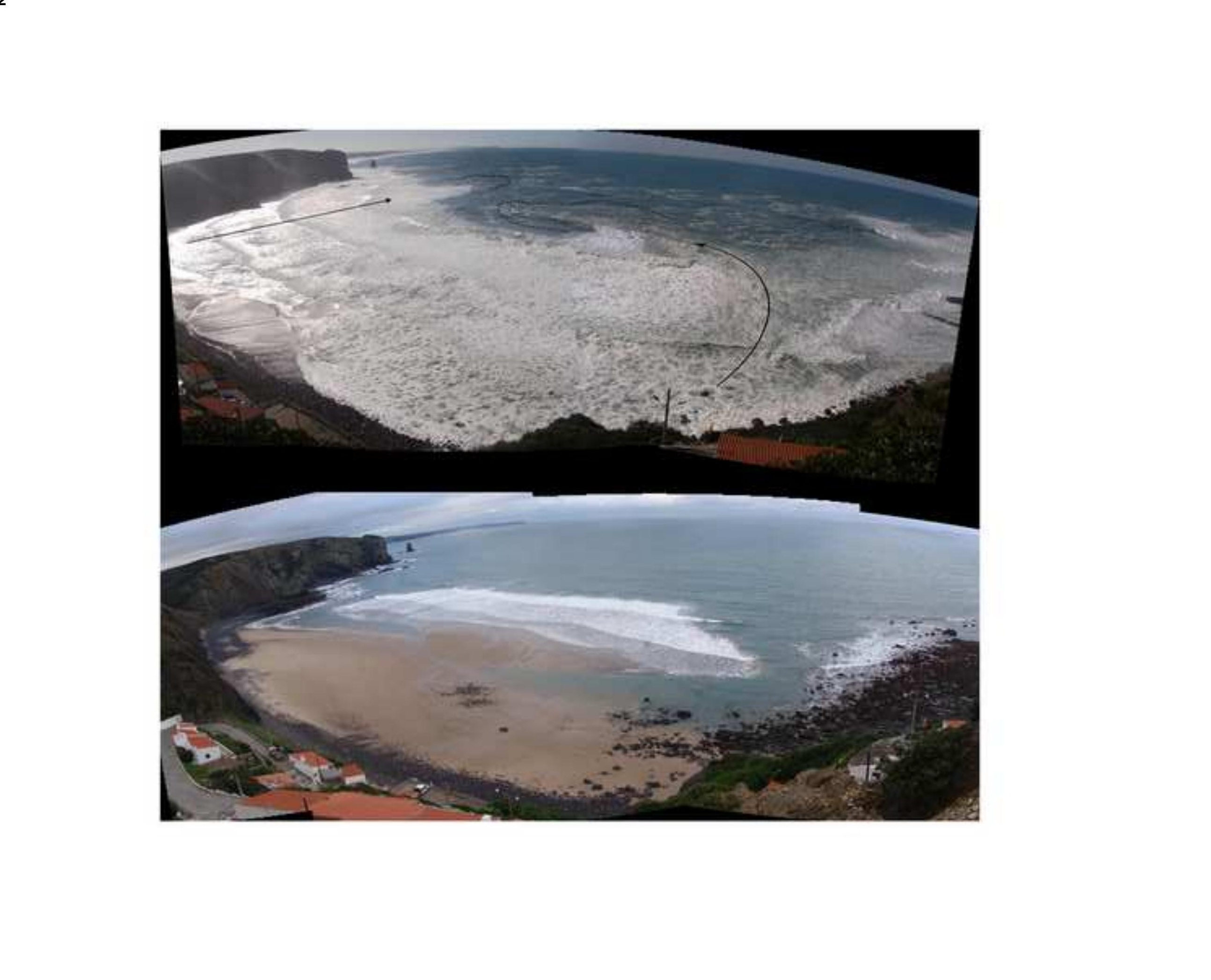

\section{Figure 1}

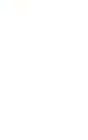
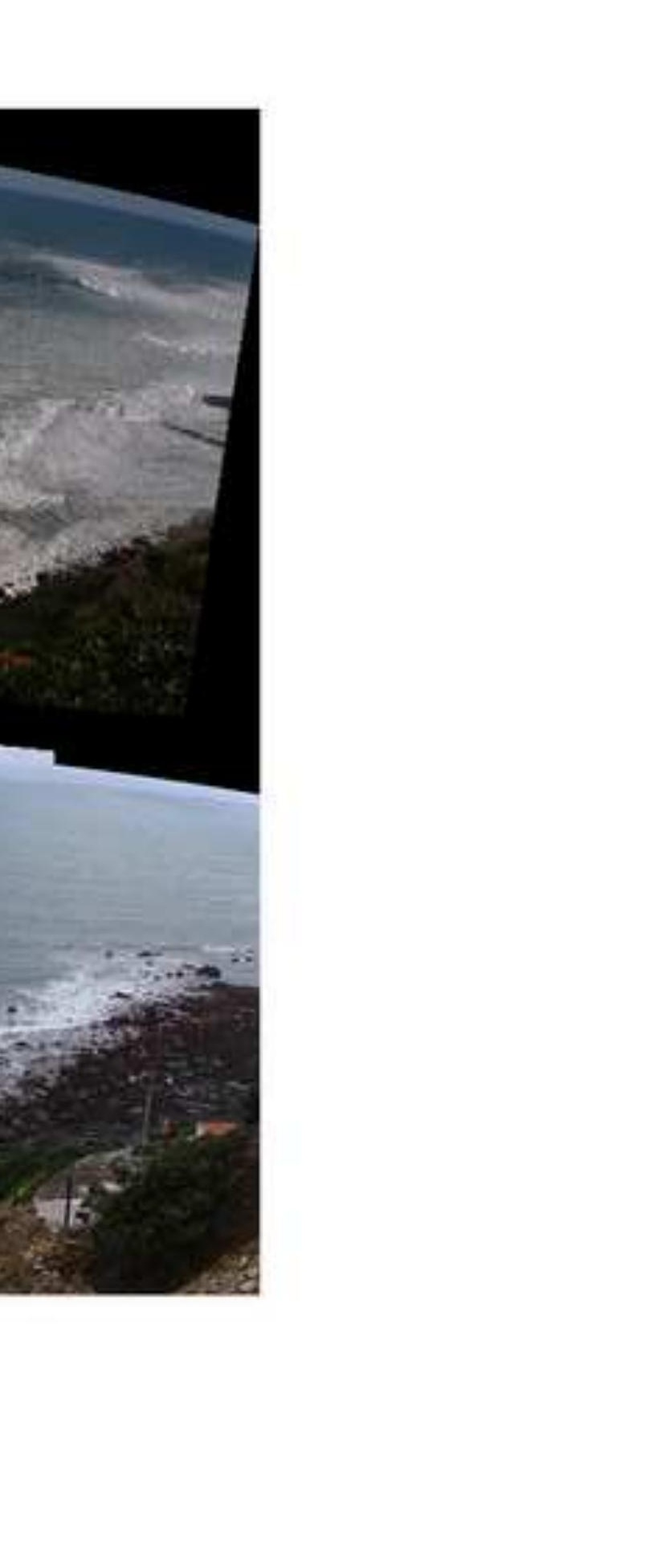

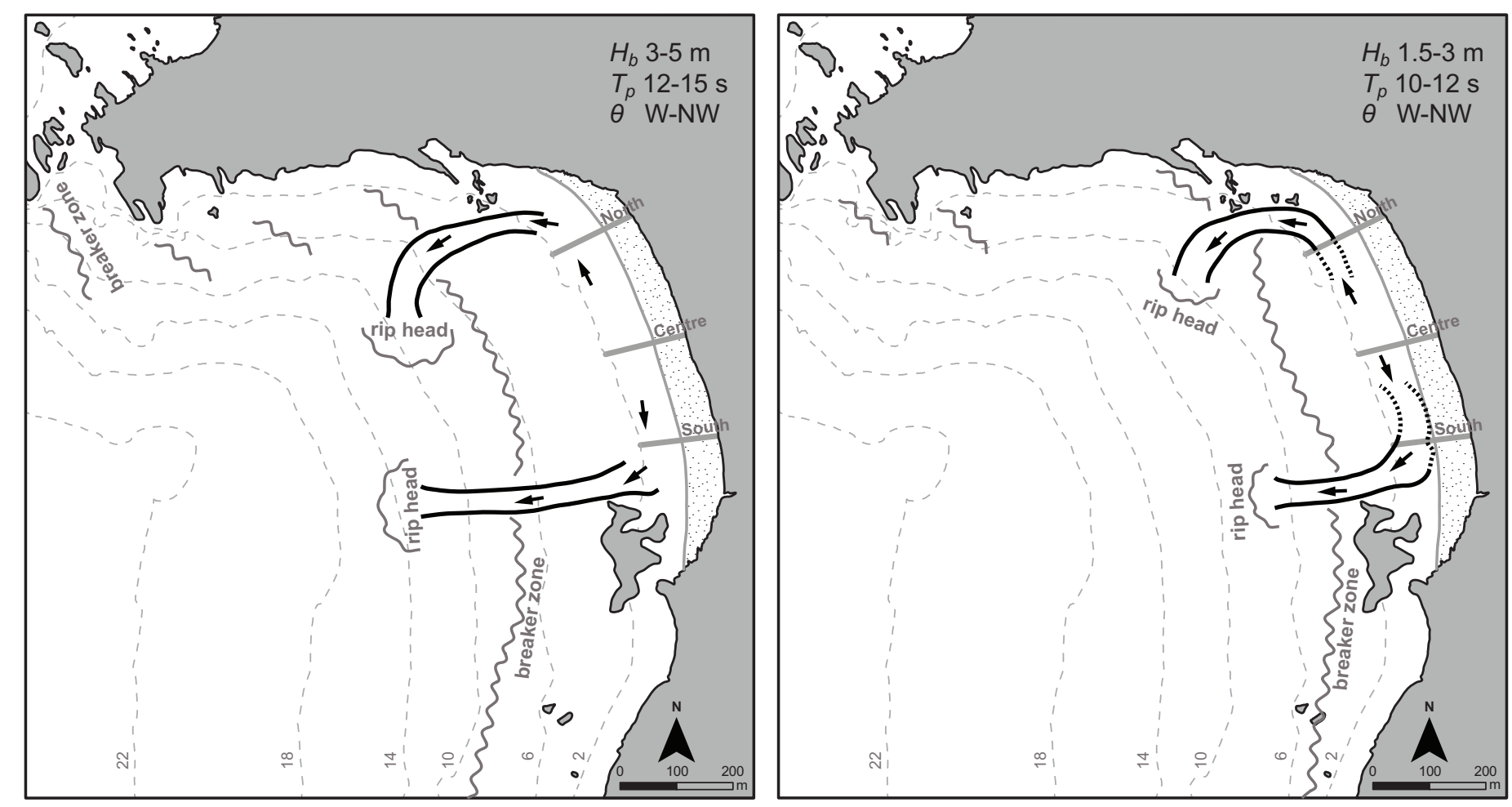
Figure 14
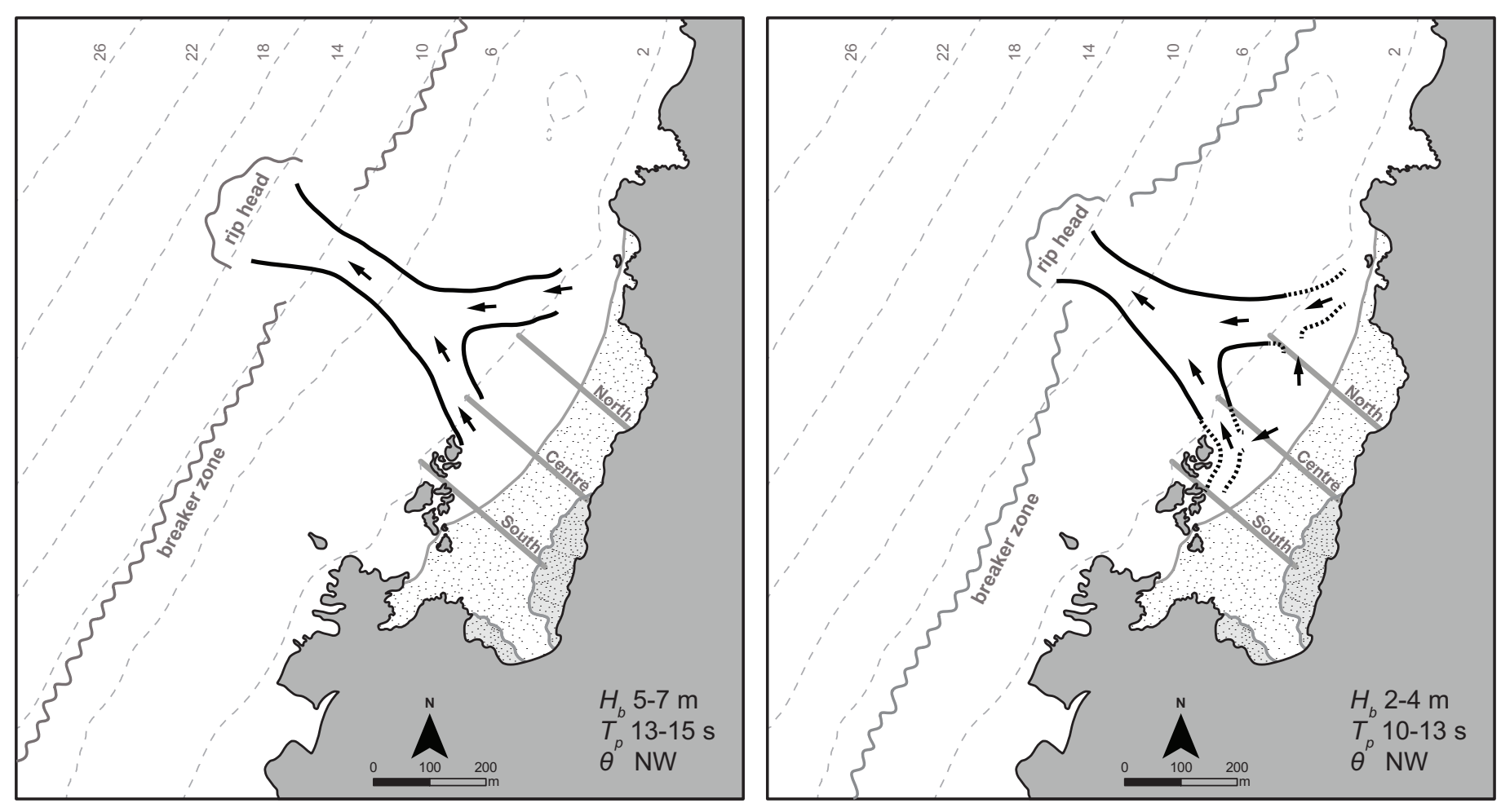
Figure 15
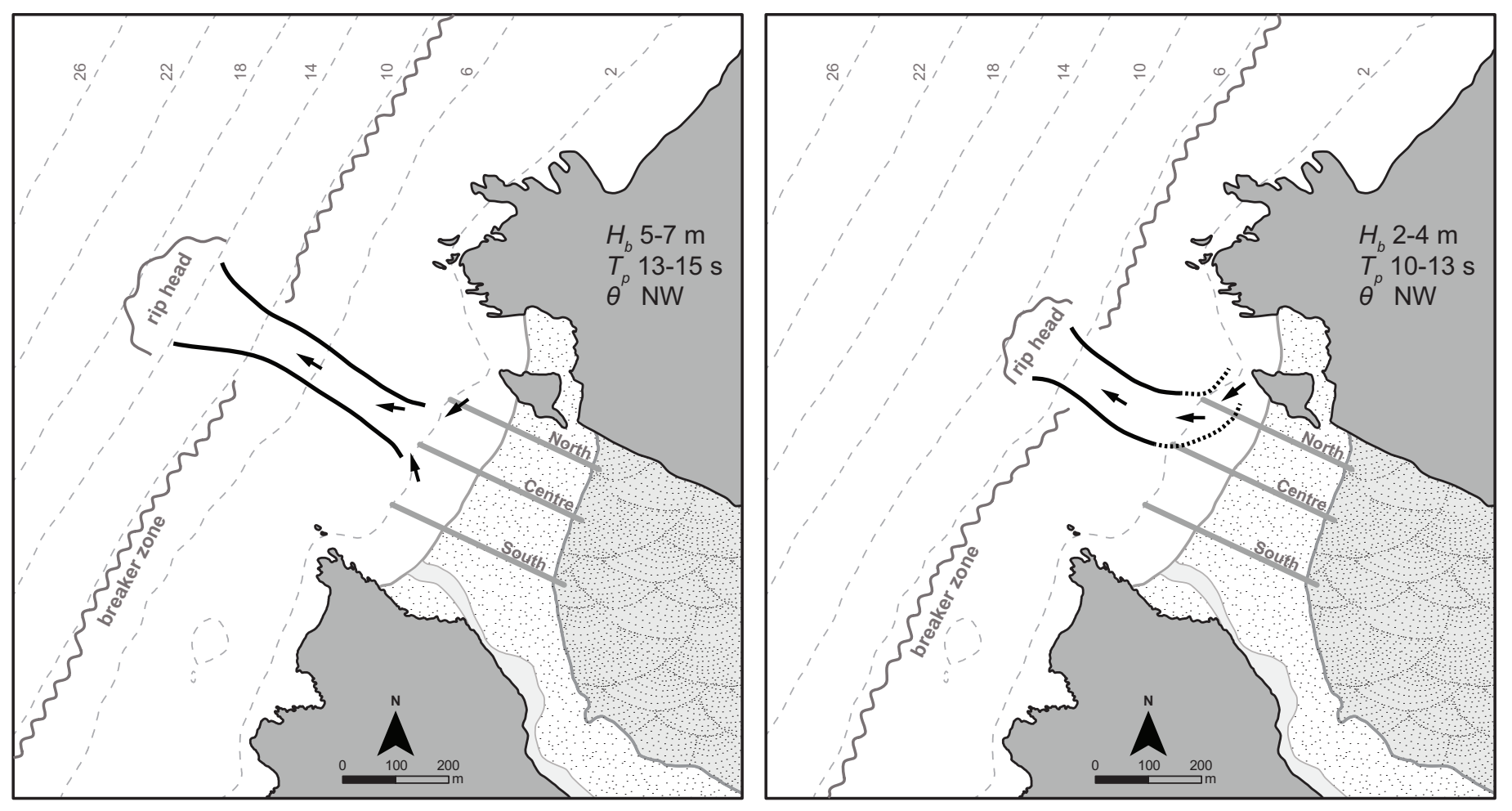